\title{
THE FUNCTIONS OF THE JURY FACTS OR FICTIONS?*
}

\author{
Dale W. Broeder $\dagger$
}

$A^{\mathrm{sth}}$

THOUGH THE JURY SYSTEM has been in vogue for more than three centuries, the functions which it performs are still only imperfectly understood. Even today the jury bears the imprint of the struggle out of which its modern characteristics emerged: More than any other institution, the jury has been the symbol of a democratic people zealous of freedom and afraid of centralized government power. ${ }^{1}$

The "jury tradition" is as much outside the law as in it. While legally charged with more or less definite administrative functions, the jury is thought to perform other functions contravening the law it is supposed to administer. These extra-legal functions are occasionally urged as the jury's chief justification. The striking fact, however, is that no one really knows how well these supposed functions are performed. Prevailing knowledge of the jury's ability to perform the strictly legal tasks assigned to it is almost equally lacking. This universal public ignorance of the jury's abilities, however, is not accidental. The "jury tradition" has been the people's sacred democratic cow. Even judges have been induced to cover jury-room deliberations with legal shrouds calculated to protect them from close public scrutiny. The few legal devices which have been created to check the performance of the jury system have proved completely ineffectual. ${ }^{2}$ Self-contained impotence has carried them into almost total disuse. ${ }^{3}$

* The views expressed herein are solely those of the author, and in no way represent any methods of approach adopted or conclusions arrived at by the members of the staff currently investigating the jury system at the University of Chicago Law School.

$\dagger$ Research Associate, University of Chicago Law School.

${ }^{1}$ See 6 Montesquieu, Spirit of the Laws 79-80 (Nugent's ed., 1949); 3 Bl. Comm. 349-50 (1778 ed.); 4 ibid., at 349. The historical critic of the jury is, of course, Bentham. See Halévy, The Growth of Philosophic Radicalism 397-403 (1928).

2 The most significant of these devices are the special verdict, the special interrogatory, and polling the jury either before or after the verdict's technical rendition as to the process by which the verdict was reached. See generally, Wicker, Special Interrogatories to Juries in Civil Cases, 35 Yale L. J. 296 (1925); Morgan, A Brief History of Special Verdicts and Special Interrogatories, 32 Yale L. J. 575 (1923); Polling to Disclose Manner in Finding Verdict, 24 Ill. L. Rev. 348 (1929).

${ }^{3}$ The utility of the special verdict was very early nullified by the requirement that the jury must find all the material facts, disputed and undisputed; nothing must be left for the judge except to pronounce judgment upon the facts found. The use of the special interrogatory 
While the jury may be a popular symbol of democracy, it is in one sense the antithesis of democratic government. The jury is responsible to no one. Its membership is anonymous. Jurors appear out of the ranks of society and as rapidly disappear back into them. The grounds for the jury's verdict are unknown. Barring extreme error, disappointed suitors must cry by themselves. This strange spectacle of an anonymous body of twelve men playing the role of one of democracy's chief symbols may well prompt examination. Consideration and comparison of the functions which the jury is ordinarily thought to perform should at least provide a tentative basis for reflection upon the current vitality and worth of the jury system in its entirety. ${ }^{4} \mathrm{~A}$ more definitive evaluation of the success with which the jury performs the many functions ascribed to it must await the completion of empirical investigations such as the one currently under way at the University of Chicago Law School. ${ }^{5}$

\section{THE JURY AS FACT-FINDER}

The jury's central legal function is to resolve the factual disputes involved in a law suit. ${ }^{6}$ The theoretically unlimited variety of issues requir-

as an aid to a general verdict and as a means of testing it has also largely proved ineffectual. "Its results are negative rather than positive. ... Innumerable refinements have been developed in ... [its] usea.and ... all in all, the practice... has not met any wide approval." Green, Judge and Jury 354-55 (1930). The polling process, except in a very few early cases, has been strictly confined to ascertaining whether the individual juror polled actually voted note 2 ,

The two most extensive bibliographies of jury material are collected by Hill, Selected Jist-of Materials on Juries, 4 Record of the Bar Ass'n of N.Y. 139 (1949), and Johnsen, The Jury System, 5 Reference Shelf, No. 6 (1928). The latter of these two works digests some of U. of Cin. L. Rev. 119 et seq. (1937) the Jury Room, 2 Ohio St. L. J. 1 (1935).

5 The current investion

was made possible by a grant from thury system at the University of Chicago Law School gation are described by Meltzer, A Projected Study afion. The projected aims of the investiAnnals of Am. Acad. of Pol. \& Soc. Sci. 97 (1953).

'The vast importance of the fact-finding function is well illustrated in a famous remark of the late Chief Justice Hughes: "An unscrupulous administrator might be tempted to say, eral principles." "N.Y. Times, people of my country and I care little who lays down the gen26 A.B.A.J. 552 (1940).

The difficulties inherent in "finding the facts" are also not the Frank has pointed out, "[T]he inherently bafti" are also not to be discounted. As Judge uncertainties account largely for legal uncertainty nature of fact-finding and the resultant the decisions of most specific law suits, especially, i.e., for the inability of lawyers to predict because of the inability in many cases to predict those not yet commenced. . . . Presumably siderable experience as a trial judge, stoted in 1921 ' ' macts,' Judge Learned Hand, after condread a law suit beyond almost anything else short of sickness and ... as a litigant I should and Music: Some Remarks on Statutory Interpretat of sickness and death." "Frank, Words 
ing adjudication will, it is felt, be best disposed of in the long run by jurors whose worldly contacts have probably touched upon a question similar to that requiring adjudication. Jurors are visualized as practical men of affairs whose daily experiences require snap judgments of the honesty and character of persons with whom they deal. Even though a juryman-cobbler may not be the best judge of whether a corporate director has violated his fiduciary obligations, the juryman-banker on the same panel may well be. Fruitful discussion will resolve the differences between them. The next case may involve a cobbler charged with larceny of shoelaces.

The jury system also supposes that the judgment of twelve men whose differences are resolved through open-minded discussion is better than the judgment of one man whose trial experience is far more extensive. Although it is historically a matter of doubt, ${ }^{7}$ the reason for requiring unanimous agreement among jurors can easily be viewed as an attempt to give litigants the benefit of a full and complete discussion of disputed issues. The requirement of twelve men is conceivably an effort to ensure that there will be differences to discuss. One man cannot differ with his own judgment and any less than twelve men will reduce the probability of differences to be discussed. A fundamental tenet of the jury tradition, then, lies in its assumption that controverted factual issues are best resolved through reasoned discussion and debate. ${ }^{8}$

The jury's fact-finding function often appears as a highly sophisticated process. The factual issues typically entrusted to the jury in civil cases, for example, cannot be decided by the exercise of reason alone. In order to submit a factual question to the jury in a civil case, the court must first determine that the question can reasonably be resolved either way. ${ }^{9}$ But if an issue can reasonably be resolved either way, the law cannot be asking the jury to decide it by the exercise of reason, for it cannot by defi-

I In all probability, the unanimity requirement is merely a primitive ancestoral hangover. According to Kluckhohn and Leighton, "The native way of deciding an issue is to discuss it until there is unanimity of opinion or until the opposition feels it no longer worthwhile to urge its point of view." Kluckhohn and Leighton, The Navajo 103 (1946).

See Barnett, Jury's Agreement-Ideal and Real, 20 Ore. L. Rev. 189 (1941); Sawyer, Jury Disagreements and the Three-fourths Rule, 10 Ohio Law Rep. 284 (1912).

9 "[The judge] is . . . supposed to submit an issue to the jury if, as the judges say, the jury can decide reasonably either way. But to say that I can decide an issue of fact reasonably either way is to say, I submit, that I cannot, by the exercise of reason, decide the question. That means that the issue we typically submit to juries is an issue which the jury cannot decide by the exercise of its reason. The decision of an issue of fact in cases of closely balanced probabilities, therefore, must, in the nature of things, be ... [other] than a rational act." Professor Michael, quoted by Curtis, The Trial Judge and the Jury, 5 Vand. I. Rev. 150, 166 (1952). 
nition be resolved in that way. In those cases where the jury is confined to passing on issues where "reasonable men may differ," therefore, the jury is to a considerable degree exercising a policy-declaring or law-making function. In such cases, the jury makes policy in the guise of "finding the facts."

The fact that an important aspect of the jury fact-finding process often consists in the enunciation of policy has significant analytical consequences. Techniques of analysis acquired from legal training and long years spent in presiding over trials, while highly desirable, perhaps essential qualities for deciding purely factual disputes, are not necessarily the most desirable qualities for the exercise of policy-making powers. The inexperience of jurors in resolving formalized factual disputes may frequently be overshadowed by the social importance of having inextricable disputes decided as twelve jurors of the community will decide them. This question is further dealt with below. ${ }^{10}$

The average juror's inexperience in handling disputes may perhaps also be discounted by the inherent nature of the fact-finding process. Eminent psychological opinion can be marshalled in support of the view that complex factual disputes are resolved not so much by a minute weighing of individual testimony as by an over-all impression garnered from viewing the evidence as a whole."1 To the extent that this, the Gestaltist theory, ${ }^{12}$ is valid, a judgment proceeding from several persons is probably as good or even better than the judgment of one man whose unconscious mental and emotional processes cannot be checked against the reactions of others. The Gestaltist theory currently seems to provide the most sophisticated justification for the familiar common law rule forbidding jurors from taking notes. ${ }^{13}$ However, the force of saying that cases are decided by emotional-intellectual reactions to testimony viewed in its entirety

10 Infra at page 395.

1 Consult the large number of authorities referred to by Frank, J., in Skidmore v. Baltimore \& Ohio Ry. Co., 167 F. 2d 54, 69 (C.A. 2d, 1948). Curtis' formulation of this theory is typical: "[T]he law quite deliberately throws the jury into as much helpless confusion as it decently can. For the law has only two choices, and one is impracticable. The law could either ask the jury to make a thorough and complete study and analysis of all the evidence, such as a lawyer does to prepare his argument on appeal. This is impracticable. Or the law could ask the jury to just listen. Any middle ground would be worse than either. For one thing is sure, the evidence has to be taken as a whole, not only all of it, but as a whole, all at one look. So anything short of a thorough restudy of it would be not simply confusing, but mislearling." Curtis, The Trial Judge and the Jury, op. cit. supra note 9, at 161.

12 While the use of the word "Gestalt" in this connection may be technically inaccurate, it has frequently been employed in literature dealing with the jury to describe the theory noted in the text. It is employed here only as a short-hand method of referring to that theory.

${ }^{22}$ See Curtis, op. cit. supra note 9, at 161. 
rather than by conscious analysis of individual facts cuts heavily into the suggested rationale for the rule requiring unanimous agreement among jurors. "General feelings" about the manner in which a case should be decided are seldom capable of being profitably discussed.

While the merits of the jury as combination fact-finder and declarer of policy may at first blush seem rather substantial, a host of factors incident to the jury's practical operation have combined to insure that this function can at best be performed only with great difficulty. Legal rules, instead of being shaped to ameliorate the effects of the jury's practical weaknesses, seem to have been almost purposefully designed to augment them. ${ }^{14}$

An excellent illustration of the positive steps the law has taken to impede the jury's successful performance of its fact-finding function is furnished by the typical jury selection process. ${ }^{15}$ The body of law governing the selection of jurors, rather than recognizing and attempting to reduce the effects of the juror's inexperience in handling legal matters, has instead exempted from service many of the groups who might best be expected to overcome this handicap. ${ }^{16}$ Professional men and women are exempted from jury duty in almost every American jurisdiction. ${ }^{17}$ Such exemptions become peculiarly incongruous in the light of the sophisticated nature of the jury's fact-finding function. The importance of having the views of professional persons who are often highly influential in molding community opinion to assist in supplying the element of policy necessary to resolve a dispute seems overwhelming.

The democratic process itself seems designed to insure the legislative exemption of persons most capable of resolving factual disputes. Jury service often involves heavy economic sacrifices, especially for those persons whose daily incomes are in excess of the per diem pittance meted out

11 See generally, Frank, Courts on Trial 108 et seq. (1949).

${ }^{15}$ See Blume, Jury Selection Analyzed: Proposed Revision of the Federal System, 42 Mich. .L. Rev. 831 (1944). Consult also, McKelway, Layman's View of Jury Service, 5 F.R.D. 207 (1946).

${ }^{16}$ The Illinois exemption statute is typical: "The following persons shall be exempt from serving as jurors, to wit: The Governor, Lieutenant Governor, Secretary of State, Auditor of Public Accounts, Treasurer, Superintendent of Public Instruction, Attorney General, members of the General Assembly ... all judges ... all clerks . . . sheriffs, coroners, postmasters, mail carriers, practicing attorneys, all officers of the United States, officiating ministers of the Gospel, school teachers... practicing physicians... registered pharmacists ... ferrymen, mayors... policemen ... members of the Fire Department, embalmers, undertakers and funeral directors ... and all persons actively employed upon the editorial or mechanical staffs and departments of any newspaper; . . . [and] all legally qualified veterinarians. . . " Ill. Rev. Stat. (1953), c. 78, §4.

${ }^{17}$ See Vanderbilt, Minimum Standards of Judicial Administration 162 et seq. (1949). 
to jurors. It is only natural to expect that groups possessing substantial influence will utilize it for the purpose of securing legislative exemption. As the groups which can exert such pressures must possess a relatively small membership, the usual result is the exemption of doctors, lawyers, dentists, and educators of every grade and description. ${ }^{18}$

The unattractive economic sacrifices incident to jury service, while in part responsible for the elimination of groups most capable of serving, has an even more undesirable aspect. Persons actively engaged in production who might be expected to possess superior character-gauging and intellectual qualities are the very persons who have an economic stake in inventing excuses sufficient to secure relief from jury duty. ${ }^{19}$ And even if they do serve, such persons have a definite economic interest in ending their periods of service as rapidly as possible. Persons suffering large economic sacrifices from jury service have much more to lose from protracted deliberations than their less fortunate colleagues.

The legal rules facilitating the elimination of persons most capable of serving on juries are carried much further than the simple process by which the typical venire is composed. Peremptory challenges, while probably desirable as a means of securing impartial jurors, are also often employed to exclude from the jury anyone "who is particularly experienced in the field of endeavor which is the basis of the law suit."20 Indeed, the use of peremptory challenges for this purpose is recommended by the leading commentaries on trial techniques. ${ }^{21}$ Such persons are likely to have too much influence with other jurors. ${ }^{22}$ The theory that the least informed are the most capable, however, would seem to be true principally for litigants whose cases are weak and who wish to pull wool over uninformed eyes. ${ }^{23}$

The process by which jurors are selected is not the only means through which the jury's fact-finding efficiency is reduced. The surroundings of inquiry during a jury trial contribute heavily to the same end. The mode of presenting evidence is disorderly; interruptions are the rule rather than

${ }^{18}$ See, e.g., the Illinois statute referrred to in note 16 supra.

19 So far as the author has been able to discover, it is only the exceptional jurisdiction which requires documentary proof from a person who either claims that he is exempt, or that he is entitled to be excused.

- 20 Goldstein, Trial Techniques 159 (1935), quoted in Frank, Courts on Trial 121 (1949).

${ }^{21}$ See generally, Goldstein, Trial Techniques (1935), reviewed by Morgan, 49 Harv. L. Rev. 1387 (1936); Longenecker, Hints on the Trial of a Law Suit (1927). And see Green, Judge and Jury 396 (1930).

2 Frank, Courts on Trial 121 (1949).

${ }^{23}$ If a litigant is sincere, he will probably desire that the most rather than the least informed should participate in resolving the dispute. 
the exception. And the evidence bearing on a particular issue is not presented all at once, but at two distinct and possibly far removed points in the course of the trial.

The feats of memory required of jurors are prodigious. Applicable legal rules are announced only after and not before the evidence is introduced. ${ }^{24}$ So far as the jurors. are concerned, the litigants' competing factual versions are presented in a non-legal vacuum. The successful integration of the facts with the law long after the facts have been presented and many of them forgotten is doubtless often impossible. Inasmuch as the legally crucial and legally unimportant aspects of the evidence are not distinguished until the trial is concluded, the jurors during the trial possess no means of knowing which aspects of the testimony they should particularly concern themselves with. The ultimate outcome of many trials must often depend on evidence which a jury considers insignificant until otherwise informed by the court. Instead of remembering the details of that which finally proves to be crucial, the average juror will instead probably recall emotional and dramatic incidents which are legally insignificant.

While the tremendous memory burdens imposed upon jurors could readily be lightened by permitting them to take notes, most jurisdictions forbid note-taking. ${ }^{25}$ Apart from the sophisticated psychological doctrine already noted, ${ }^{26}$ the common law rule's most forceful justification is that jurors differ in note-taking ability. ${ }^{27}$ If the prohibition were removed, efficient note-takers would be in a position to exert a disproportionate influence upon the jury's deliberations. ${ }^{28}$ While this justification may have

21 In Indiana, however, the trial judge is obliged to instruct the jury as to the issues for trial, the burden of proof, the credibility of witnesses and the manner of weighing the testimony to be received before counsel are permitted to make their opening statements. 2 Burns Ind. Stat. Ann., Supreme Court Rule 1-7a (Supp., 1951); and see Hartshorne, The Timing of the Charge to the Jury, $33 \mathrm{~J}$. of Am. Jud. Soc. 90, 91 (1949). In addition, a minority of juristhis practice, while it may be desirable, does not reach the objection noted in the text. See generally, Blatt, Judge's Charge to Jury Should Precede Arguments of Counsel, 33 J. Am. Jud. Soc. 56 (1949).

25 "[T]he principle that jurymen should not take notes ... seems to be established in all common law states ... except ... Georgia where by decision the right has been recognized, with the proviso that the court should not allow the jury to spend too much time taking notes so as to let that phase of the trial take their minds away from their real duty." Woodcock, Note Taking by Jurors, 55 Dick. L. Rev. 335, 336-37 (1951).

26 Note 13 supra and accompanying text.

${ }^{27}$ See the discussion of this question in Bomberger, Jurors Should Be Allowed to Take Notes, 32 J. Am. Jud. Soc. 57 (1948); McNagny, Jurors Should Not Be Allowed to Take Notes, 32 J. Am. Jud. Soc. 58 (1948).

28 Another argument which occasionally appears is that many people place too much value upon the written word. Compare the interesting results found by Hunter in his interrogation of jurors: "The lack of attention given to exhibits, such as X-ray pictures, and to the written 
possessed some degree of merit when most jurors were unable to read or write, it is currently nonsensical. Carried to its logical conclusion, it would require the exclusion of all jurors of superior mentality. The intelligent juror will almost always exercise more influence than his fellows. ${ }^{29}$ This observation considerably undermines the validity of the traditional assumptions concerning juror unanimity and the sacred number "twelve."

Even if it is assumed that jurors ordinarily possess the native intellectual ability necessary to absorb and retain vast amounts of factual material, the fullest employment of their faculties is severely impeded by the circumstances under which most trials are conducted. ${ }^{30}$ The typical trial is surcharged with emotion. The calm essential for dispassionate deliberation and the retention of large amounts of testimony is almost entirely absent. ${ }^{31}$ Not only are the factual questions involved in a trial frequently more complex than those with which most jurors are familiar, but, "jurors hear ... evidence in a public place, under conditions of a kind to which they are unaccustomed: No juror is able to withdraw to his own room, or office, for private individual reflection. And, at the close of the trial, the jurors are pressed for time in reaching their joint decision. Even twelve experienced judges, deliberating together, would probably not function well under the conditions we impose on the twelve inexperienced laymen." 32

Apart from a few rules such as those preventing the admission of extremely prejudicial evidence, the courts have done little to restrain counsel from awakening the prejudices and arousing the passions of jurymen. In Tennessee, an advocate's right to cry before the jury has been pitched above the constitution, as "one of ... [those] natural rights ... which no Court or constitution ... [can] take away." 33 Indeed, it is a "serious ques-

instructions and pleadings which go to the jury room was surprising." Hunter, Law in the Jury Room, 2 Ohio St. L. J. 1, 18 (1935).

29 See Barnett, Jury's Agreement-Ideal and Real, op. cit. supra note 8.

so "The parties are keyed up to the contest; and the topics are often calculated to stir up the sympathy, or prejudice; or ridicule of the tribunal. . . . The longer the trial lasts, the larger the scanning crowds, the more intensely counsel draw the lines of conflict, the more solemn the judge, the harder it becomes for the jury to restrain their reason from somersault." Frank, Courts on Trial 118 (1949).

' al Compare, however, the extremely high scores which jurors recorded as to facts presented in the courtroom in the studies of Hoffman and Brodley, Jurors on Trial, 17 Mo. L. Rev. 235 (1952). This can probably be explained by the fact that a large percentage of the persons involved in the test had received some college training. Compare with the Brodley and Hoffman studies those of Professor Hunter, op. cit. supra note 4.

32 Frank, Courts on Trial 119-20 (1949).

- ${ }^{33}$ Ferguson v. Moore, 98 Tenn. 342, 351, 39 S.W. 341, 343 (1897). 
tion" in Tennessee "whether it is not ... [counsel's] professional duty to shed ... [tears] whenever proper occasion arises." 34 The lawyer's professional duty to make the best possible use of the juror's emotions is urged in countless treatises on trial techniques, ${ }^{35}$ including a study written under the auspices of the American Bar Association. ${ }^{36}$ The advocate who can successfully appeal to prejudice, arouse the jurors' passions, and cloud the issues, instead of being pilloried by his associates, is canonized. It is no wonder that the courts look with kindly indulgence upon such rules as those permitting plaintiff's counsel in a paternity suit to parade the sorrowful mother with babe in arms before the jury, or to force the putative father to stand before his peers so that the jury can ascertain the purportedly close resemblance between the child's characteristics and his own. ${ }^{37}$ The toleration bestowed upon counsel's efforts to create sympathy for his client or to engender the jury's prejudice against his opponent is also mirrored in the willingness of "liberal" appellate courts to overlook "mildly inflammatory remarks." 38 The willingness of these same courts unhesitatingly to reverse for almost insignificant errors in the trial court's instructions to the jury seems anomalous. While jurors may often be influenced by inflammatory remarks calculated to excite prejudice, it is probably the exceptional case in which a small error in the trial court's instructions influences the jury one way or another. ${ }^{39}$

The striking degree to which the circumstances surrounding a jury trial differ from those in which jurors resolve factual disputes in private life is again apparent from an examination of the evidential materials upon which jurors rely in arriving at decisions in the two types of situations. While hearsay statements and the opinions of persons whom the juror respects often loom very large in the process leading up to his decisions in private life, the use of both hearsay and opinion in the courtroom is

34 Ibid.

${ }^{35}$ See the works referred to in note 21 supra.

${ }^{36}$ Gair, The Trial of a Negligence Action (1946).

${ }^{37}$ See, for example, the liberal views of the California court in Berry v. Chaplin, $74 \mathrm{Cal}$. App. 2d 652, 169 P. 2d 442 (1946).

${ }^{38}$ Ibid. And see Frank, Courts on Trial 117 n. 6 (1949).

${ }^{39}$ With a single exception, all the jury studies thus far are in agreement that a large number of jurors do not comprehend the court's instructions and frequently disregard them. Hoffman and Brodley, Jurors on Trial, 17 Mo.L. Rev. 235 (1952); Hervey and Murrah, 18 Okla. Bar Ass'n J. 1508 (1947); Wanamaker, 11 U. of Cin. L. Rev. 191 (1937); Hunter, Law in the Jury Room, 2 Ohio St. L.J. 1 (1935). Compare Moffat, As Jurors See a Lawsuit, 24 Ore. L. Rev. 199, 204 (1945). Moffat's questioning of 1500 jurors as to whether they understood the court's instructions resulted in the affirmative responses preponderating over the negative ones in the ratio of about twenty to one. 
sharply restricted. The intricate web of evidential rules governing the receipt of testimony in jury trials seems poorly calculated to take advantage of whatever native decision-making abilities jurors possess.

However, in view of the sophisticated nature of the jury's fact-finding function in many cases, the reply to the contention that jurors can make little use of their native abilities in the courtroom might be that it really doesn't matter. As such questions can by definition reasonably be resolved either way, it is not necessary that jurors possess even average fact-finding abilities.

Several important objections can be urged against such an analysis. First of all, it is only in civil cases that the law confines the jury's factfinding province solely to questions upon which "reasonable men may differ." In criminal cases, the jury is entrusted with all factual questions, whether reasonable men can differ on them or not. And even in civil cases, the necessary consequence of having the jury decide even one issue is to entrust the entire case in to its hands. ${ }^{40}$ The usual lawsuit involves numerous factual questions. Although "reasonable men may differ" on how some of these questions may be resolved, there may be little basis for reasonable differences of opinion regarding others. Yet the generally employed practice of either permitting or requiring the jury to return a general verdict renders the court unable to ascertain the precise ground upon which the verdict rests. ${ }^{41}$ In addition, there are degrees of reasonableness. While experts might agree, for example, that reasonable men could differ as to how a given factual issue should be resolved, there is nevertheless a theoretically correct way to decide every such question. The more rational course for deciding the point seems to dictate the calling of more experts rather than submitting the issue to twelve laymen.

As already noted, ${ }^{42}$ the second most important justification of the view that the jurors' fact-finding abilities are immaterial is the theory that factual analysis is useless anyway and that the outcome of lawsuits principally depends upon the jurors' simple reactions to the evidence viewed in its entirety. If this contention is correct, the jury's verdict in many cases must be contrary to the law as declared in the instructions of the court. The Gestaltist theory of the decisional process assumes that a verdict will be returned for the litigant who appears best entitled to victory on the

\footnotetext{
${ }^{40}$ Although only liability questions are being considered at this point, this is true both of liability and damage.questions. Some of the most forceful criticisms of the jury have been directed against its inability properly to handle damage problems.

"See text and notes at page 418 infra.

12 See text and notes at page 389 supra.
} 
basis of the testimony as a whole, with no regard for particular aspects of the case..$^{43}$ In a negligence action, for example, although the plaintiff may have established beyond question that the defendant was negligent and is clearly entitled to a verdict on the basis of the evidence considered as a whole, on the issue of contributory negligence the plaintiff's case might just barely be strong enough to avoid a directed verdict. for the defendant. Yet on the theory that a factual analysis of the testimony is immaterial, the Gestalt theory would require that a verdict be directed for the plaintiff. Logically extended, the "snapshot theory" of the decisional process necessitates eliminating the jury in all cases where reasonable men could not differ about which party satisfied the Gestaltist-burden of showing that most of the factual disputes should be resolved in his favor. Furthermore, the Gestaltist doctrine ignores the jury's legal duty to decide factual disputes in accordance with law, and negates the theory that the jury rationally declares policy in the guise of finding facts. Rational balancing of conflicting community policies is impossible if a verdict must in any event be returned for the litigant who satisfies the burden of showing that most of the evidence is slanted in his favor.

In view of the jury selection process and the vastly difficult conditions under which jurors labor, the theory that most jurors can correctly apply involved legal rules to complicated factual disputes, disregarding all testimony erroneously admitted, and in all other respects obey the court's instructions seems highly suspect.4 In many cases jurors will probably not even understand the legal rules announced by the court. Even lawyers cannot always accurately comprehend them. As Judge Jerome Frank has pointed out:

To comprehend the meaning of many a legal rule requires special training. It is inconceivable that a body of twelve ordinary men ... could, merely from listening to the instructions of the judge, gain the knowledge necessary to grasp the true import of the judge's words. For these words have often acquired their meaning as the result of hundreds of years of professional disputation in the courts. The jurors usually are as unlikely to get the meaning of those words as if they were spoken in Chinese, Sanskrit, or Choctaw. 45

In numerous ways the courts appear to have recognized this. The development of legal rules governing motions for a new trial, the directed verdict, as well as demurrers to the pleadings and evidence bear too close a connection with the evolution of the modern jury trial to be pure historical

13 See note 12 supra.

${ }^{44}$ What semi-scientific data is available seems to support this statement completely. See particularly, Hoffman and Brodley, Jurors on Trial, 17 Mo. L. Rev. 235 (1952).

Frank, Courts on Trial 116 (1949). 
accidents. ${ }^{46}$ All of these doctrines are merely mechanisms for transferring the burden of decision from the jury to the court, thus avoiding the risk that the jury will err in cases where the evidence is clearly all on one side. The flowering of various per se liability rules can be similarly explained. ${ }^{47}$

Many of the doctrines governing the admission of evidence amply reflect the low esteem in which courts have traditionally held the average juror's fact-finding abilities. ${ }^{48}$ Particularly is this true in such areas as relevance and materiality, where evidence, if admitted, is likely to create an unjustifiable prejudice or confuse the issues. While some doubt has been cast on the thesis that the inception of evidentiary rules in most cases corresponds with the emergence of the jury as an established factfinding body, ${ }^{49}$ the continued vitality of the jury is certainly the principal justification for their retention today..$^{50}$

But the assumption of evidence law that the jury is ill-equipped to decide factual disputes is not consistently maintained. Thus, "[it] often happens ... that an item of testimony will have a highly and illegitimately prejudicial effect upon one issue and a substantial, legitimately logical value upon another. The court then, with an inconsistency born of necessity, assumes that the jury which has not sufficient capacity to make the necessary discriminations upon the first issue has the ability to perform the psychological feat of disregarding the item entirely upon the first issue and of confining its influence to the second issue."

${ }^{16}$ See the excellent discussion in Green, Judge and Jury 375-94 (1930).

${ }^{17}$ E.g., the familiar Pennsylvania stop-look-and-listen rule which requires a directed verdict for the defendant if the plaintiff has failed to stop at a railroad crossing. See text and notes at page 407 infra.

18 See generally, Morgan, The Jury and the Exclusionary Rules of Evidence, 4 Univ. Chi. L. Rev. 247 (1936).

19 Compare Morgan: "Our exclusionary rules of evidence are the resultant of several factors. Ancient ideas as to the reliability of witnesses have had their influence. Judicial convictions that the privilege of suppressing the truth is essential to the fostering of certain socially desirable relationships and to the protection of the citizen from persecution have played a large part. The adversary theory of litigation is directly responsible for many of them; and judicial distrust of the jury for not a few; but the dictum ... that the English law of evidence is 'the child of the jury' is . . . not more than a half-truth." Morgan, op. cit. supra note 48, at 258 .

so The most important qualification to this statement would seem to lie in the area of testimonial privileges.

sI Morgan, op. cit. supra note 48 , at 249 . Alternating judicial regard for and distrust of the jury's abilities is apparent elsewhere than in the law of evidence. The vast feats of memory required of jurors, the highly-refined assumption that the jury can analyze and correctly apply complex legal instructions and the jury's duty to resolve krotty factual disputes are totally inconsistent with such rules as those prohibiting the court from commenting upon the evidence for fear that the jury will be too much influenced. A recent federal case, Butler v. United States, 188 F. 2d 24 (App. D.C., 1951), reversed the trial judge for failure to instruct the jury that the court's facial expressions during the trial were not to be considered. See Note, 
Finally, if society regarded jurors as more capable fact-finders than trial judges, we should expect that the numerous exceptions to the right of trial by jury would not have arisen. In this respect, there is little excuse for distinctions so subtle as that between a fraud action for damages and an action for recision in equity based upon the same facts.

A brief appraisal of the consequences which have resulted from the jury's function as finder of facts gives added perspective from which to view the success which the jury has exhibited in this capacity. These consequences are profound.

While the jury cannot be charged with responsibility for necessitating the troublesome distinction between questions of fact and law, it has certainly heightened the significance of the distinction. The social quest for legal rules adapted as guides to future conduct, coupled with the laymen's total lack of understanding in legal affairs, must early have given rise to the practice of judicial instructions concerning the law. While it was for the jury to decide "pure questions of fact," it was the province of the court to advise the jury on "matters of law." The judicial practice of instructing the jury on matters of law has probably been the most fruitful. source of error in our jurisprudence..$^{52}$ As already noted, appellate courts have displayed a strange fear that jurors will be misled by instructions which the courts in other connections seem to recognize that many jurors probably cannot even understand..$^{53}$

In addition to errors in the court's instructions to the jury, the distinction between law and fact may result in the submission of a question to the jury which an appellate court later decides was a question of law for the court. ${ }^{54}$ Whatever service the jury performs as a convenient device for

Criminal Procedure, Facial Expressions and Gesticulations of Trial Judge, 5 Vand. L. Rev. 236 (1952). The greatest inconsistency of them all, however, is presented by the case of Louisville \& Nashville Ry. Co. v. Gower, 85 Tenn. 465, 3 S.W. 824 (1887). The Tennessee Supreme Court reversed the trial court, in a negligence case, for instructing the jury that due care "was just such care as one of you, similarly employed, would have exercised," as it didn't appear that the jurors were men of ordinary care. Ibid., at 474 and 827.

32 Green, Judge and Jury 351 (1930); see also, Orfield, Criminal Procedure from Arrest to Appeal 449 (1947); Orfield, Criminal Appeals in America 200 (1939); Rossman, The JudgeJury Relationship in the State Courts, 3 F.R.D. 109 (1943); Farley, Instructions to Juries, 42 Yale L. J. 43 (1932).

s3 See articles cited note 52 supra. To some extent such errors could be avoided through intelligent use of the special verdict. Nordbye, Use of Special Verdicts, 2 F.R.D. 138 (1943); McCormick, Jury Verdicts upon Special Questions in Civil Cases, 2 F.R.D. 176 (1943). In several states, special verdicts are used even in criminal cases. A.L.I. Code of Criminal Procedure 1000 (1931).

54 See, e.g., Morris, Law and Fact, 55 Harv. L. Rev. 1303 (1942); Issacs, The Law and the Facts, 22 Col. L. Rev. 1 (1922). 
separating factual and legal questions (thus preventing future cases involving different facts from being governed by a combined set of legal and factual determinations valid only for the case in which they were first employed), ${ }^{55}$ seems outweighed by the deleterious effects produced by frequent disputes concerning the scope of legal and factual questions and by the jury's fact-finding difficulties in general.

Erroneous comments on the evidence, ${ }^{56}$ and irrelevant, inflammatory, or prejudicial remarks of counsel or court are additional sources of error stemming from the jury's fact-finding function. ${ }^{57}$ Evidential errors furnish an even more frequent cause for reversal; and are, indeed, often the only means by which an appellate court can overturn a verdict which has a reasonable basis in the evidence, but which the court feels morally certain is in error. ${ }^{58}$

The well-intrenched distinction between law and equity can in some measure also be ascribed to the jury. The numerous cases dealing with the proper scope of appellate review would long ago have ceased to have meaning had litigants not been permitted the opportunity of wrangling over the right to a jury trial. ${ }^{59}$ Procedural errors resulting from uncertainty as to when jury trials may be obtained under merged procedure afford an additional cause for expense and delay. ${ }^{60}$

Another chief consequence of the litigants' right to a jury trial is seen in the effects produced upon the courts' willingness to utilize modern sci-

ss While not previously emphasized, the use of the jury for the purpose of separating questions of law and fact has also been urged as one of the jury's less important functions. Dickinson, however, has assigned it pre-eminence. Dickinson, Iegal Rules: Their Application and Elaboration, $79 \mathrm{U}$. of Pa. L. Rev. 1052-53 (1931). It must be admitted that combiner legal and factual determinations by equity courts and by law courts sitting without juries have sometimes worked injustices. But such instances have been comparatively infrequent. Consult Chafee, Simpson, and Maloney, Cases on Equity 1058-59 (1951).

s6 While the Supreme Court has stated that the constitutional right of trial by jury presupposes a judge empowered to advise on the facts, Capital Traction Co. v. Hof, 174 U.S. 1 (1899), yet in a majority of states, constitutional provisions, statutes, or judicial decisions deny the trial judges this privilege. The limits of the privilege are not even clear in the Federal courts. See Note, Federal Judge's Expression of Opinion on Merits Held to Abridge Right to Jury Trial, 52 Harv. L. Rev. 698 (1939). See also, Sunderland, The Problem of Trying Issues, 5 Tex. L. Rev. 18, 32 (1926); Symposium, The Right of a Judge to Comment on the Evidence in His Charge to the Jury, 6 F.R.D. 317 (1946).

${ }^{37}$ Jury waiver problems occasion an additional source of error. See Note, 59 Yale L. J. 345,346 et seq. (1950).

${ }^{58}$ The numerous devices which have been created to take questions from the jury, such as demurrers to the pleadings or evidence and the directed verdict also occasion frequent grounds for delay. Errors in the impaneling of the jury should also be mentioned. (1937).

59 See generally, Clark and Stone, Review of Findings of Fact, 4 Univ. Chi. L. Rev. 190

${ }^{60}$ The Right to Jury Trial under Merged Procedures, 65 Harv. L. Rcv. 453 (1952). 
entific techniques. ${ }^{61}$ Fearing the undue weight which the average juror might attach to these techniques, the courts have either severely restricted their use or prohibited them from being used altogether. ${ }^{62}$ As the evidential rules governing the receipt of scientific testimony have been carried over to cases at law tried without juries, and to cases in equity, the result has been to stultify considerably the over-all sophistication of judicial inquiry. And even where such techniques are admitted as evidence, the degree of conclusiveness which science attaches to them has often been ignored. ${ }^{63}$ Oddly enough, courts which greatly restrict the use of many kinds of scientific techniques for fear of the jury's inability to accord them proper weight, also frequently assume that jurors possess sufficient technical ability to detect error in the most complicated scientific experiment. The attitude of the California court in the case of Berry v. Chaplin, ${ }^{64}$ permitting the jury to return a verdict in the face of uncontroverted and unimpeached scientific testimony that the defendant could not have been the father of the plaintiff's child, is typical of many tribunals. ${ }^{65}$ The rationale of such decisions rests on the assumption that the jury.must have "felt" there was error in the conduct of the experiment. Concededly, however, disregard of scientific facts has not always been confined to juries. ${ }^{66}$

The crudity of legal administration necessitated by the jury is exemplified in rules other than those governing the admissibility of scientific techniques. ${ }^{67}$ A significant portion of the evidential doctrines restricting or precluding the rational use of lay and expert opinion testimony can also

o1 The following articles are extremely useful: Smith, Scientific Proof, 52 Yale L. \$. 586 (1943); Morgan, Suggested Remedy for Obstructions to Expert Testimony by Rules of Evidence, 10 Univ. Chi. L. Rev. 285 (1943). For a comprehensive list of the literature on this subject, consult 10 Univ. Chi. L. Rev. 369 et seq. (1943).

${ }_{02}$ Mumford, Disregard of Scientific Proof by Juries, $41 \mathrm{~J}$. Crim. L. and Criminology 320 (1950); Smith, Scientific Proof and Relations of Law and Medicine, 10 Univ. Chi. L. Rev.' 243, 277 (1943); Smith, Scientific Proof, 52 Yale L. J. 586 (1943).

${ }^{83}$ E.g., Jordon v. Davis, 143 Me. 185, 57 A. 2d 209 (1948); Arais v. Kalensnikoff, 10 Cal. 2d 428, 74 P. $2 d 1043$ (1938); compare Jordan v. Mace, 144 Me. 351, 69 A. 2d 670 (1949).

6474 Cal. App. 2d 652, 169 P. 2d 442 (1946).

${ }^{65}$ See cases cited note 63 supra.

${ }^{66}$ Thus, Arais v. Kalensnikoff, 10 Cal. 2d 428, 74 P. 2d 1043 (1938), upon which the Berry case rests, involved, not a jury, but a trial judge sitting without a jury. The California Supreme Court there sustained a verdict for the plaintiff, not only in the face of uncontroverted scientific testimony that the defendant could not have been the father of the child, but in spite of the following additional facts: (1) the defendant was married to another woman; (2) the mother had named a man other than the defendant as the father in the child's birth certificate; and (3) the defendant was seventy years of age and, according to his wife, had been impotent for a number of years.

67 That this crudity works both for and against defendants in criminal cases, see Streeter and Belli, The "Fourth Degree": The Lie Detector, 5 Vand. L. Rev. 549 (1952). 
be ascribed to the jury. ${ }^{68}$ The familiar rubric concerning illicit invasions of the jury's fact-finding province, on the ultimate issues and otherwise, furnishes the most frequently expressed basis for such doctrines. ${ }^{69}$ Judicial skepticism of the jury is also mirrored in the well-established doctrine that life-expectancy and annuity tables are to be employed only with great caution, if at all. ${ }^{70}$ The Pennsylvania court has refused to sanction the use of annuity tables by the jury under any circumstances, remarking that, "The less jurors are burdened with complicated tables and the necessity for complex calculations, the more likely will they be to do substantial justice." ${ }^{\prime 11}$ And even where such tables are admitted, the jury's discretion is safeguarded unless clearly erroneous. ${ }^{72}$ Particularly is this true of cases arising under wrongful death statutes. ${ }^{73}$ Rules pertaining to the use of statistical aids in determining damages, however, are merely one aspect of the widespread influence of the jury in the shaping of damage law. ${ }^{74}$ In many cases, the jury's inability to do anything but speculate on the amount of the plaintiff's damages results in a complete denial of recovery, despite the fact that valid statistical means of estimating them exist. ${ }^{75}$ Such cases are in striking contrast to the vast disparity in damage awards reflected in jury verdicts in all types of litigation. ${ }^{76}$

\section{The Jury as Judges of the LaW}

It was apparently the view of Mr. Justice Holmes that the jury's functions might on occasion extend to the decision of questions of law which would bind the court in future litigation involving different parties. In the

68 See, e.g., Ladd, Expert Testimony, 5 Vand. L. Rev. 414 (1952); Maguire and Hahesy, Requisite Proof of Basis for Expert Opinion, 5 Vand. L. Rev. 432 (1952). Compare Morgan: "It can ... safely be asserted that there is no objectionable feature of the opinion rule which considerations looking to the protection of the jury can be relied upon to explain or justify." Morgan, op. cit. supra note 48 at 252.

69 "The objection most consistently voiced to exclude expert opinion is that such testimony "invades the province of the jury." " Expert Testimony as an "Invasion of the Province of the Jury," 26 Iowa L. Rev. 819 (1941).

${ }^{70}$ McCormick, Damages 306 et seq. (1935).

71 Moore v. Leininger, $299 \mathrm{~Pa} .380,385,149$ Atl. 662, 664 (1930).

72 McCormick, Damages 307 (1935). $\quad{ }^{73}$ Ibid., at 361.

71 To mention only one example, rulings which exclude evidence of business profits designed to establish the value of plaintiff's working time rest almost entirely on judicial fear of swollen verdicts. Ibid., at 312 .

${ }^{75}$ This has been particularly true where the nature of the interest injured is highly ephemeral, such as a "chance"" or a "mere expectancy." McCormick, Damages 120 et seq. (1935).

76 "Awards for similar injuries, age and income considered, are widely variant in amount, even where there is no real contest over liability and consequently no attempt to compromise liability and amount." Ibid., at 306-7. 
Massachusetts case of Commonwealth v. Sullivan, ${ }^{77}$ Holmes declared that as the legal question of whether "bank-nite" was a lottery had been determined in the affirmative by a jury in the earlier case of Commonwealth v. Wright, it was "not necessary to go on forever taking the opinion of the jury," but that the jury's verdict in the Wright case had finally determined the question. ${ }^{78}$ The power to create precedents, long thought to be an exclusively judicial function, was thus placed within the province of the jury as well as the court.

But the Holmesian view concerning the proper scope of the jury's lawmaking function, however influential in jurisprudential theory, has not prevailed in the courtroom. The Holmes' opinion in Commonwealth $v$. Sullivan excepted, no case has been uncovered in which a court has shown itself willing to share stare decisis powers with a body of twelve laymen. The resolution of statutory ambiguities for the purpose of providing legal standards to guide future adjudication has remained a strictly judicial function.

While the jury tradition has not as yet engulfed the courts' stare decisis powers, the jury has, in a variety of contexts, been charged with the duty of declaring law for particular cases. Three questions must be carefully distinguished: (1) the jury's duty to declare the law in opposition to what the trial judge says the law is; (2) the jury's duty to decide, pursuant to legal standards laid down by the court, whether a given type of conduct or group of events falls within a legal rule; and (3) the jury's duty to inject an element of community sentiment into its resolution of issues upon which reasonable men may differ. The third of these questions having already been discussed, ${ }^{79}$ only the first and second remain for consideration.

As late as 1794, in the case of Georgia v. Brailsford, ${ }^{80}$ Chief Justice Jay was stating that the jury's functions in civil cases encompassed the duty; of disregarding the court's instructions on the law if the jury felt them to be erroneous. Several other early American cases support a similar doctrine. ${ }^{81}$ Indeed, in the period following the Revolutionary War, the jury's duty to ignore whatever legal rules it felt were unjustified was considered

77146 Mass. 142, 15 N.E. 491 (1888).

${ }^{78}$ Ibid., at 145 and 494.

${ }^{79}$ See pages 388 and 395 supra.

${ }^{80} 3$ Dall. (U.S.) 1 (1794).

81 See, e.g., Van Horne v. Dorrance, 2 Dall. (C.C. Pa.) 304 (1795); Bingham v. Cabot, 3 Dall. (U.S.) 18 (1795). An extensive list and summary of the leading cases is contained in Sparf and Hansen v. United States, 156 U.S. 51 (1895). 
of such importance in Georgia that it was constitutionally safeguarded.82 So far as civil cases are concerned, however, this aspect of jury supremacy over the law has completely disappeared and it is everywhere settled that the jury must in civil cases take the law as the court's instructions direct.

In criminal cases, recognition afforded the jury's duty to decide the law in opposition to the stated views of the trial court has been much more .widespread. $^{83}$ In several states, explicit constitutional provisions were adopted to safeguard it. ${ }^{84}$ In Illinois, for example, the constitution was thought to permit counsel to argue judicial opinions before the jury as late as $1931 .{ }^{85}$ By a gradual process of judicial emasculation, however, state constitutional provisions empowering the jury in criminal cases to decide legal questions have been rendered meaningless. The formerly well-entrenched criminal law notion that the jury is rightfully entitled to disregard the law as given in the court's instructions has now been repudiated in all states but Indiana and Maryland. ${ }^{86}$

The question of whether the jury could legally disregard the instructions of the court was at last conclusively settled for the federal system in the case of Sparf and Hansen $v$. United States. ${ }^{87}$ The majority of the Court, by Justice Harlan, held that the jury is bound, in criminal as well as civil cases, to follow the judge's instructions upon all matters of law. Justice Gray, with Justice Shiras concurring, vigorously dissented in a seventy-three page opinion. ${ }^{88}$ While the major portion of both opinions is superficially concerned with a disposition of prior cases, the crucial issue, certainly for the majority, was whether it could be admitted that the jury had the right to dispense with the operation of law in particular cases and, in effect, to declare statutes unconstitutional. In several glowing rhetorical passages which can easily be read as an elevation of stare decisis prin-

\& Ga. Const. Art. XII (1777).

${ }^{83}$ The constitutional provisions and cases are collected in an excellent articlc by Howe, Juries as Judges of Criminal Law, 52 Harv. L. Rev. 582, 589 (1939).

"I Ibid.

${ }^{85}$ An Illinois statute, passed pursuant to a constitutional provision of 1818 , long interpreted to give counsel the right to argue questions of law before a jury, was finally declared unconstitutional in 1931. People v. Bruner, 343 Ill. 146, 175 N.E. 400 (1931). The highly specious nature of the majority's reasoning is well pointed out in the dissenting opinion of Justice Duncan. Ifid., at 167 and 408. Compare Commonwealth v. Austin, 7 Gray (Mass.) 51 (1856), and Commonwealth v. O'Connell, 274 Mass. 315, 174 N.E. 665 (1931).

${ }^{80}$ See Lynch v. State, 9 Ind. 541 (1857); Wheeler v. State, 42 Md. 563 (1875). However, it seems clear from later decisions in both jurisdictions that the position taken in these early cases is continually being eaten away. Howe, op. cit. supra note 83, at 614 n. 126 .

$" 7156$ U.S. 51 (1895).

ss Ibid., at 110 et seq. 
ciples to the level of constitutional law, ${ }^{89}$ the Court spoke eloquently of the need for uniformity of statutory interpretation and administration, for a government of law and not of men, for legal signposts lighting the way for future adjudication as contrasted with the hit-or-miss blackness of the jury's general verdict on the law. For Justice Gray, ${ }^{90}$ the issue was liberty against uniformity, the need for flexibility as opposed to the mechanical desire of the majority to place everyone on the same administrative level. Both Harlan and Gray conceded the power of the jury to suspend the law; they differed over the jury's right to do it. Jerome Frank ${ }^{91}$ and others have argued that no practical distinction can be drawn between jury power and jury right. But this implies that the distinction is meaningless. Actually, the practical implications of Justice Gray's position are profound. An admission by the nation's highest Court that twelve laymen are more capable of deciding law than trial judges would probably have led to a drastic modification of the jury system. In an important sense, therefore, the real friend of the jury was not Gray, but Harlan.

The position of the majority in Sparf and Hansen, that uniformity of adjudication is superior to flexibility in individual cases, is in striking analytical contrast to the universally recognized function of the jury to decide, pursuant to legal standards laid down by the court, whether a certain type of conduct or group of events falls within a given legal definition. A consistent application of the "government by law" rationale constituting the basis for the Sparf ruling seems to require that the jury be deprived of the right to decide questions of law under all circumstances. ${ }^{92}$ Theoretically, of course, the "government by law" principle is not necessarily opposed to current practice. The jury can be conceived of as deciding in accordance with law because it is the law that the jury should decide what the law is. Practically, however, different juries must frequently decide law differently and uniformity in the administration of justice becomes impossible. General verdicts are not stare decisis; no records are even kept of them. ${ }^{93}$

${ }^{89} \mathrm{Mbid}$., at 102-3. $\quad{ }^{90} \mathrm{Ibid}$, at $110 . \quad{ }^{91}$ Frank, Courts on Trial 112 et seq. (1949).

92 Entrusting the jury with the decision of legal questions runs counter to our entire tradition and to many of our deep seated legal rules, such as the ex post facto and bill of attainder clauses, the constitutional prohibition on vaguely drawn statutes, and the ejusdem generis limitation of catch-all provisions.

93 "Jury-made law, as compared with judge-made law, is peculiar in form. It does not issue general pronouncements. You will not find it set forth in the law reports or in textbooks. It does not become embodied in a series of precedents. It is nowhere codified. For each jury makes its own law in each case with little or no knowledge of or reference to what has been done before or regard to what will be done thereafter in similar cases." Frank, Law and the Modern Mind 173-74 n. $\ddagger$ (1930). 
The determination of whether certain conduct falls within a particular legal category has frequently been left to the jury on the theory that such a determination involves a "mixed question of law and fact." "94 In one sense, at least, all such questions are "mixed questions of law and fact."95 Yet in a very large number of cases, the fitting of facts into a legal rule is held to involve a "pure question of law." 96 Thus, the question raised by a demurrer to an indictment in an ordinary criminal case on the ground that the facts alleged do not charge an offense is the same type of question as that involved in determining whether a book is obscene or whether a defendant acted as a reasonably prudent man. On demurrer, all three cases raise the issue of whether certain conceded facts fall within a general rule of law. Yet the first of these issues is everywhere held to be a "pure question of law," while the latter two issues are denominated "mixed questions of law and fact." ${ }^{\prime 97}$ It is apparent that the use of such labels is merely a convenient method of characterizing which of such questions are for the court and which are for the jury.

That the phrase "mixed question of law and fact" represents a mere legal conclusion, however, does not detract from the significance of the consequences resulting from its use. When a court characterizes an issue as involving a "mixed question of law and fact" it is almost universally sent to the jury and, more important, cannot be taken from the jury if reasonable men can differ on how it should be resolved.

The most familiar example of a "mixed question of law and fact" con-

'See generally, Bohlen, Mixed Questions of Law and Fact, 72 U. of Pa. L. Rev. 111 (1924); and Sloovere, The Functions of Judge and Jury in the Interpretation of Statutes, 46 Harv. L. Rev. 1086 (1933), and references there cited.

95 Thus, the question of whether certain facts fit within a given legal category is certainly as much a fact as whether the defendant shot $X$. An "issue of law" is also involved, as the question of what consequences flow from certain conceded facts necessarily involves a question of

The line demarcating questions of law for the court from combined questions of law and fact which are for the jury has never been clear. The most plausible rationale governing the distinction seems to hinge upon a question's relative importance. If the court feels that a question decisively affects some crucial public interest, the court itself will decide it. This perhaps explains the inconsistency that the question of probable cause in a malicious prosecution action is for the court to determine, although it seems much the same as the question of "due care" left to the jury in negligence cases. The reason for the malicious prosecution rule is the danger that juries might reach verdicts which would deter people from volunteering information concerning suspected criminals. See generally, Stern, Review of Findings of Administrators, Judges and Juries: A Comparative Analysis, 58 Harv. L. Rev. 70 (1944); Morris, Law and Fact, 55 Harv. L. Rev. 1303, 1323 et seq. (1942).

P. E.g., Marcus v. Boston Evidence Co., 317 Mass. 1, 56 N.E. 2d 910 (1944); Crabb v. Comm'r of Int. Rev., 121 F. 2d 1015 (C.A. Sth, 1941); Jordan v. City of Hannibal, 87 Mo.
673 (1885).

${ }^{97}$ See discussion at page 409 infra. 
sists in the jury's determination in negligence cases of whether a defendant has acted reasonably. ${ }^{98}$ While the question of whether the defendant acted reasonably is a "question of fact" in the sense that he either did or did not perform certain acts which a prudent man would have performed, it also involves a "question of law." For to determine what a prudent man would have done is to define particularly the legal standard which the defendant's conduct must meet in order to avert liability for negligence. When the jury decides whether the defendant acted reasonably, it is not deciding a "pure question of fact," such as whether a dog drowned or the defendant struck Brown. Of course, preliminary questions concerning the existence of a legal duty on the part of the defendant to act reasonably toward the plaintiff and whether reasonable men could differ on whether this legal duty was violated are questions for the court. ${ }^{99}$ It is also the court's function to instruct the jury on the nature of the defendant's legal duty in general; the defendant should have acted as a reasonably prudent man considering all of the circumstances under which the accident took place. But it is for the jury rather than the court to say. what was reasonable under the circumstances, and to fit into the court's general definition the facts of a particular case..$^{100}$

It is perfectly conceivable that the law should have legal standards of reasonableness covering a large variety of particular situations. The progressive fashioning of such rules was advocated by Justice Holmes, ${ }^{102}$ and has had considerable influence in tort law generally. It must be emphasized, however, that particularized standards of reasonableness cannot at present be formulated if reasonable men might arrive at a different result on a given set of facts. For to do so would involve an invasion of a litigant's right to a trial by jury. ${ }^{102}$

${ }^{88}$ See generally, James and Sigerson, Particularizing Standards of Conduct in Negligence Trials, 5 Vand. L. Rev. 697 (1952); James, Qualities of the Reasonable Man in Negligence Cases, 16 Mo. L. Rev. 1 (1951); James, Functions of Judge and Jury in Negligence Cases, 58 Yale L. J. 667 (1949); Seavey, Negligence: Subjective or Objective?, 41 Harv. L. Rev. 1 (1927).

${ }^{99}$ See, e.g., James, Functions of Judge and Jury in Negligence Cases, 58 Yale L.J. 667 (1949).

${ }^{100}$ Technically, the jury's finding of what is reasonable is merely an implied finding, a negative one. The jury need not, for example, determine what precisely the defendant had to do in order to act reasonably, but only that he did or did not act reasonably. E.g., Grant v. Graham Cher-Cola Bottling Co., 176 N.C. 256, 97 S.E. 27 (1918); Wolf v. Des Moines El. Co., 126 Iowa 659, 98 N.W. 301 (1905).

${ }^{101}$ E.g., Holmes, The Common Law 110, 124 et seq. (1881). Compare Detroit \& M. R. Co. v. Van Steinberg, 17 Mich. 99, 120 (1868).

102 "The test is not what we ourselves think . . but what in our best judgment a trier of the facts might think ... without going beyond the bounds of ... reason. This distinction 
The Pennsylvania stop-look-and-listen rule furnishes perhaps the most familiar illustration of a judicially prescribed standard of reasonableness for a particular situation. ${ }^{103}$ Regardless of unusual circumstances, such as visual obstructions, rain, snow, or fog, or even an actual invitation to cross, the plaintiff's failure to stop before crossing a railroad track is negligence per se. ${ }^{104}$ The rule "is not a rule of evidence, but a rule of law, peremptory, absolute and unbending; and the jury can never be permitted to ignore it, to evade it or to pare it away by distinctions and exceptions." 105 Numerous other examples of judicially created rules governing particular situations could also be mentioned. ${ }^{106}$ Their vitality, however, is on the wane ${ }^{107}$ and they have always been exceptions to the normal rule that the particular standard of reasonableness is a question for the jury.

The principal argument favoring a judicial particularization of legal rules in negligence cases is the added predictability which would result from taking such questions from the jury. ${ }^{108}$ Currently, the only instance in which the court is legally empowered to formulate a particularized standard of conduct is.where reasonable men could not differ regarding its correctness. If the courts were always required to determine the precise legal nature of the defendant's conduct, negligence law would be much more predictable. Whatever injustice may exist under current practice, however, is said to be justified by the fact that defendants can be negligent in a vast number of ways, and that stare decisis codification of particularized rules is impossible. A corollary of this notion is that codification would produce more injustice than it would alleviate. It is doubtful

... is familiar. It . . must be preserved if jury trial is to be preserved." Commonwealth $v$. Isenstadt, 318 Mass. 543, 556, 62 N.E. 2d 840, 847 (1945). While this statement is drawn from a case involving an obscenity prosecution rather than a negligence case, the principle involved is the same.

${ }^{103}$ E.g., Pennsylvania R. Co. v. Aiken, 130 Pa. 380, 18 Atl. 619 (1889). Compare City of Elkins v. Western Md. Ry. Co., 76 W. Va. 733, 86 S.E. 762 (1915), stating the more generally accepted view.

101 E.g., Benner v. Philadelphia \& Reading Ry. Co., 262 Pa. 307, 105 Atl. 283 (1918).

${ }^{105}$ Ibid., at 311 and 284.

${ }^{106}$ E.g., the rule adopted in many states that it is negligence per se to be unable to stop within the range of vision, that a motorist must blow his horn when a pedestrian is about to step in front of his car, or that a power company must insulate its high tension wires.

${ }^{207}$ Compare, e.g., Baltimore \& Ohio R. Co. v. Goodman, 275 U.S. 66 (1927), with Pokora v. Wabash Ry. Co., 292 U.S. 98 (1934).

108 s'[I]f men are told in advance just what they may and may not do, the inhibiting fear of uncertainty will be removed as a stumbling block in the way of desirable affirmative activity." James, Particularizing Standards of Conduct in Negligence Trials, op. cit. supra note 98, at 705 . 
whether these arguments alone are powerful enough to counter-balance the undesirable effects of the uncertainty resulting from the submission of such questions to the jury. A more decisive consideration, however, is that most negligence actions arise out of factual settings in which the nonexistence of precedents concerning reasonableness is immaterial. It is an extraordinary individual who consults a lawyer before deciding to drive in excess of a given speed, or before making a left-hand turn without signaling properly. Yet the reasons justifying the practice of submitting the negligence issue to a jury in civil cases are probably insufficient to justify a similar practice in criminal negligence actions. Not only is there a greater need for predictability in criminal cases, but the pressing necessity of administering justice even-handedly between two similarly situated and equally culpable defendants applies with much greater force in criminal cases.

The lack of predictability resulting from the practice of entrusting "mixed questions of law and fact" to the jury is not confined to the law of criminal negligence. Indeed, the practice seems unjustified in any instance where the social policies underlying the need for predicitability and equality before the law overshadow the difficulties attendant upon the formulation of particularized legal rules. In the resolution of constitutional questions, for example, the need for predictability is paramount. Yet there are currently a large number of combined legal and factual determinations in this area which are left to the jury. In a recent Maryland case, ${ }^{109}$ for example, the jury was permitted to determine whether the plaintiff was denied the equal protection of the laws because of an alleged inadequacy of Negro as contrasted with white public golf facilities. So far as third parties are concerned, of course, the general verdict which resulted left the question as unsettled as before the litigation began. Other equally unjustified examples of the above practice are afforded by the submission to the jury of the "just rate"110 and "just compensation"111 issues involved in public utility and eminent domain litigation. Only last term the Court sustained the New York practice of leaving the question of whether a confession is voluntary to the jury, ${ }^{112}$ even though the effect of the practice is virtually to deprive defendants of any independent determination of the voluntariness issue whatever. The mixed legal and factual question involved in determining whether a statute is "reasonable" has also occasionally been left

${ }^{109}$ Durkee v. Murphy, 181 Md. 259, 29 A. $2 d 253$ (1943).

${ }^{110}$ E.g., United Gas Public Service Co. v. Texas, 303 U.S. 123 (1937).

11 E.g., Chicago B. \& Q. R. Co. v. Chicago, 166 U.S. 226 (1896).

${ }^{122}$ Stein v. New York, 346 U.S. 156 (1953). See Meltzer, Involuntary Confessions: The Allocation of Responsibility between Judge and Jury, 21 Univ. Chi. L. Rev. 317 (1954). 
to the jury. ${ }^{113}$ Indeed, support for such a practice can be found in the judicial opinions of the nation's highest Court. ${ }^{114}$

Currently, however, the practice of entrusting mixed questions of law and fact to the jury has worked its most unfavorable effects in the law of free speech. The doctrine that First Amendment rights are particularly worthy of protection, ${ }^{115}$ and that all attempts to infringe upon them must pass the most rigid judicial scrutiny would seem to require that such questions be kept from the jury at all costs. Actually, however, the exact opposite is true. In an obscenity case, for example, the issue of a book's obscene character is generally held to be a question for the jury. And, because a "mixed question of law and fact" is said to be involved, the question raised by the defendant's demurrer on the ground of the indictment's failure to state an offense is not whether the book is obscene, but whether twelve jurors could reasonably differ on its obscene character. ${ }^{116}$ As already noted, however, the question raised by the defendant's demurrer in an ordinary criminal case is held to involve a "pure question of law." Thus, if $\mathrm{A}$ is indicated. for an attempted murder and it is alleged as constituting such an attempt that A purchased a gun with the intent to shoot $\mathrm{X}$, on A's demurrer the court would determine, not whether reasonable men could differ as to whether these acts constituted an attempt, but whether they do so as a matter of law. ${ }^{117}$ A person about to commit arson,

113 See Soref, The Doctrine of Reasonableness in the Police Power, 15 Marquette L. Rev. 1 (1930), and cases there cited. See also, 5 McQuillin, Municipal Corporations 447-48 (3d ed., 1949).

14 See Atlantic \& Pacific Tel. Co. v. Philadelphia, 190 U.S. 160 (1903); Postal TelegraphCable Co. v. New Hope, 192 U.S. 55 (1904). Cf. Chastleton Corp. v. Sinclair, 264 U.S. 543 (1924); Laurel Hill Cemetery v. San Francisco, 216 U.S. 358 (1910); Prentis v. Atlantic Coast Line, 211 U.S. 210, 227 (1908).

In few areas of the law is legal certainty more at a premium than in the area where federal and state authority dovetails and lawyers, on the pain of losing everything for their clients, are required to pick the correct statute under which to bring an action. Yet, even here, the courts have held that where the facts are in dispute or where more than one reasonable inference can be drawn from undisputed facts, the question of whether an employce was engaged in interstate commerce at the time of an accident, so as to enjoy the protection of the Federal Employers' Liability Act, is a question for the jury. Avance v. Thompson, 387 Ill. 77, 55 N.E. $2 d 57$ (1944); Pennsylvania Co. v. Donat, 239 U.S. 50 (1915). Indeed, in the Pennsylvania case, the Court characterized the opposing view as "frivolous." Ibid., at 51.

115 See the discussion and citation of authorities in United States Supreme Court's Rules of Self-Limitation as Applied to the Fundamental Rights of the First Amendment, 33 Minn. L. Rev. 390 (1949).

116 Commonwealth v. Isenstadt, 318 Mass. 543, 62 N.E. 2d 840 (1945); United States v. Dennett, 39 F. 2d 564 (C.A. 2d, 1930); People v. Pesky, 254 N.Y. 373,173 N.E. 227 (1930). See also, People v. Seltzer, 122 Misc. 329, 203 N.Y. Supp. 809 (S. Ct., 1924).

${ }^{117}$ See, e.g., People v. Rizzo, 246 N.Y. 334, 158 N.E. 888 (1927); People v. Jaffe, 185 N.Y. 497, 78 N.E. 169 (1906); State v. Mitchell, 170 Mo. 633, 71 S.W. 175 (1902); Commonwealth v. Kennedy, 170 Mass. 18,48 N.E. 770 (1897). 
rape, murder or some other crime involving what the courts have analyzed as a "pure question of law" can consult judicial opinions discussing precisely what acts constitute these offenses. Yet a person about to write a book which could conceivably be labeled obscene is deprived of precedents discussing precisely what books are obscene. ${ }^{118}$ The lack of predictability attendant upon submitting the obscenity issue to the jury simply results in inhibiting people from experimenting with new art forms. To this extent, of course, the scope of the First Amendment's free speech protection is curtailed.

Almost all free speech cases have been held to involve "mixed questions of law and fact." For example, the issue of whether a defendant's speech activities constitute a clear and present danger has frequently been left to the jury. ${ }^{119}$ The contrary practice approved in Dennis $v$. United States ${ }^{120}$ probably only extends to cases where the scope of the danger alleged to be clear and present is world-wide, ${ }^{121}$ or at the most, to cases where the scope of the alleged danger involves a prediction of an alleged danger's future magnitude. ${ }^{122}$ There is little question that the jury's determination of the clear and present danger issue is still the ordinary and legally accepted practice. ${ }^{123}$ The result, of course, is again to deprive the political reformer of valuable judicial determinations on just what speech activities the First Amendment protects.

Cases involving negligence, obscenity, libel, slander, indecency, and certain types of political free speech are the principal instances in which the jury has been given the right to decide law, even for particular cases. The negligence exception to the rule that legal questions are solely for the

118 As Judge Learned Hand puts it, "the verdict of the jury is not the conclusion of a syllogism of which they are to find only the minor premise, but really a small bit of legislation ad hoc." United States v. Levine, 83 F. 2d 156, 157 (C.A. 2d, 1936).

While there are at least three and possibly four views concerning the legal definition of obscenity, all of them involve an implied finding by the jury of the prevailing standards of community morality. See Alpert, Judicial Censorship of Obscene Literature, 52 Harv. L. Rev. 40 et seq. (1938).

119 "Whether the printed words would in fact produce as a proximate result a material interference with the recruiting or enlistment service... was a question for the jury in view of all the circumstances of the time, and considering the place and manner of distribution. Schenck v. United States, 249 U.S. 47, 52; Frohwerk v. United States, 249 U.S. 204, 208; Debs v. United States, 249 U.S. 211, 215." Pierce v. United States, 252 U.S. 239, 250 (1920). 579.

120341 U.S. 494 (1951). Justice Black based his dissent partially on this ground. Ibid., at

${ }^{121}$ Richardson, Freedom of Expression and the Function of the Courts, 65 Harv. L. Rev. 1 et seq. (1951).

${ }^{122}$ See the opinion of Jackson, J., in Dennis v. United States, 341 U.S. 494, 578 (19.51).

${ }^{123}$ Richardson, op. cit. supra note 121. 
court can perhaps be rationalized. ${ }^{124}$ The other exceptions cannot be. The practical effect of submitting these questions to the jury is to deprive groups such as authors, playwrights and political reformers of legal standards by which to guide their conduct. Libel, slander, obscenity and political free speech situations would seem to require, because of their very "amorphousness," a higher degree of "advance legal notice" than any other kind of case. Legal rules here, if anywhere, are essential to government by law. ${ }^{125}$

\section{The Jury as Law Dispenser}

The power of the jury to dispense with the operation of law in particular cases has often been heralded as its greatest function. ${ }^{126}$ The flexibility of administration made possible by the general verdict is said to render otherwise impersonal legal rules human and to supply the needed filling out of the exceptions necessarily left unprovided for in any rational legal system. ${ }^{127}$ The law-dispensing function of the jury also makes gradual change possible and is an expediter in the implementation of community sentiment. ${ }^{128}$ Jury verdicts permit laws to anticipate the democratic proc-

124 It must be admitted, however, that the distinction taken in the text between the jury's law-making duties in negligence as contrasted with obscenity cases has not been recognized. See, e.g., the remarks of Hand, J., in United States v. Levine, 83 F. 2d 156, 157 (C.A. 2d, 1936), in which the jury's law-making function in negligence and obscenity cases is said to be the same.

${ }^{125}$ Judicial willingness in recognizing the importance of according to defendants reasonable notice of what the law is in ordinary criminal cases, when the question of an indictment's legal sufficiency is for the court, is nowhere better illustrated than in the relaxation of the maxim that "ignorance of the law is no excuse" whenever the law is so uncertain that the defendant could not possibly have known what it was. See Note, 62 Harv. L. Rev. 1393 (1949); Hall, General Principles of Criminal Law 364-72 (1947). Why this consideration has not had influence in cases where legal questions are left to the jury is nowhere explained.

${ }^{126}$ See, e.g., Wyzanski, A Trial Judge's Freedom and Responsibility, 65 Harv. L..Rev. 1281, 1285-86 (1951); Curtis, The Trial Judge and the Jury, 5 Vand. L. Rev. 150, 166 (1952); Wigmore, A Program for the Trial of a Jury Trial, $12 \mathrm{~J}$. Am. Jud. Soc. 166 (1929); Pound, Law in Books and Law in Action, 44 Am. L. Rev. 12, 18-19 (1910).

${ }^{127}$ E.g., Holmes: "[O]ne reason why I believe in our practice of leaving questions of negligence to [the jury] ... is what is precisely one of ... [its] gravest defects from the point of view of [its] theoretical function: that [jurors] ... will introduce into their verdict a certain amount-a very large amount, so far as I have observed - of popular prejudice, and thus keep the administration of the law in accord with the wishes and feelings of the community." Holmes, Law in Science and Science in Law, 12 Harv. L. Rev. 443, 459-60 (1889).

Holmes is not speaking of the jury's strictly legal function as fact-finder, in which the law has accorded the jury ample room for injecting community sentiment into issues upon which reasonable men may differ. He is instead praising jury lawlessness, the process by which juries nullify laws although the facts on which their de facto legal determinations are based are ones upon which reasonable men could not differ. These two questions are entirely different.

${ }^{128}$ The more sophisticated advocates of jury lawlessness pose anarchy as the alternative to a general verdict: 'There is a . . . 'socially adapted intuitive law'-which evolves in the various 
ess. While the fiction of stability is maintained until the legislature can act, the law is enabled to move ahead by dispensing with itself. ${ }^{129}$

Several observations can be made concerning the jury's law-dispensing function. In the first place, we do not know how well it works; the verdict is a seal of secrecy which the law has thus far refused to open. While it is generally recognized that juries often return verdicts contrary to law, we cannot be sure whether this results from conscious law-dispensing or pure bungling. For many juries, the conscientious application of the court's instructions to the facts may result in an unconscious dispensing with the law. ${ }^{130}$ Juries themselves do not always know what they are doing. ${ }^{131}$ Furthermore, exceptions to the ordinary legal rules work both ways. Persons who look with favor upon the jury's legislative powers generally think only one way, of the murder case, for example, where the defendant shot his wife's paramour in a fit of blind rage, or where the community's most able and God-fearing doctor administered poison to put his best friend out of misery. Where the prejudices of the community are shrouded in the verdict's mystery to carve out an exception from a rule whose normal operation would permit the defendant to go free, law-dispensing becomes less palatable. The bona-fide white male conviction of a Negro for leering at a white girl at a distance of over sixty feet is a Southern exception to the ordinary assault rule. ${ }^{132}$ Other examples must be legion; the whitewashing of lynchers is also law-dispensing.

In addition to being an inconsistent law-dispenser, the jury is in many

communities to which we belong. . . . [E]ach has its own rules of conduct. . . . The positive law proclaimed by the state cannot do violence to the law-consciousness of the people without creating serious tensions in society." Berman, The Challenge of Soviet Law, 62 Harv. L. Rev. 220, 449-51 (1949).

${ }^{129}$ Judge Wyzanski puts this notion forward as an excuse for trial judge failure adequately to instruct the jury upon the law, and to lecture against allowing emotional considerations to enter into the deliberations. As the jurist says, "[J]udges sense a new climate of public opinion which rates security as one of the chief goals of men." Wyzanski, A Trial Judge's Freedom and Responsibility, op. cit. supra note 126, at 1285-86.

${ }^{130}$ The thesis that juries dispense with law assumes that they understand it, and, as pointed out above, this is in many cases highly questionable.

${ }^{131}$ Furthermore, the courts do everything possible to keep the legislative materials, such as whether the defendant is insured, away from the jury. If jurors are to legislate, we should take pains to equip them properly. As it is, the poor soul who the jury "thought" was insured has become a national tragedy.

${ }_{132}$ Chicago Sun Times, p. 19, col. 1-2 (Nov. 12, 1952). On appeal, the judgment was reversed because a man cannot be convicted of an assault merely "for what may have been in his mind." State v. Ingram, 237 N.C. 197, 74 S.E. $2 d 532$ (1953). In reversing the judgment, the Court noted that, "A careful observance ... of the ... statute regulating the compilation of jury lists and prescribing the sources of information to aid in determining the qualifications of those listed would do much to improve the quality of juries." Ibid., at 204 and 537. 
respects a highly unrepresentative one. ${ }^{133}$ If the jury is designed to function as a minor legislature, it should represent a total cross-section of the community. ${ }^{134}$ The fact is, of course, that democratic processes cannot always produce changes which juries have effected. In many cases, no person would vote for the abolition of a law which he might readily ignore in his capacity as juror. In other cases, of course, we may predict with more or less certainty that the legislature will ultimately effectuate the changes juries have sought to implement. Familiar examples are found in the largely outmoded fellow-servant rule, and in the doctrine of contributory negligence. It is probable, however, that the legal remains of these doctrines would long ago have passed out of our law had not the jury made their presence less disturbing. Instead of facilitating desirable changes in the law, jury verdicts may in many cases retard such changes. Meanwhile, juries are permitted to deal differently with persons who are similarly situated. The long hours lawyers spend in assembling juries is ample evidence of this. The incidence of typical jury room legislation has probably, in the long run, benefited comparatively few. The most telling objection which can be urged against the exercise of the jury's power to dispense with the law, however, is that it is contrary to law and to the "government by law" principle. Men who act arbitrarily all too frequently act unjustly. And it makes little sense to tell jurors to follow the law, while hoping and recognizing that they will disobey it anyway. ${ }^{135}$

\section{The Jury's Function in CrInINal Cases}

While the jury currently occupies a sacrosanct position in civil cases, its position in criminal litigation is doubly secure. Possibly this is a mere re-

133 " [T] $]$ he . . fact . . . is that the jury has never been regarded as a purely democratic institution. ... It is common knowledge that in all ... states many people who vote... are nevertheless deprived of the privilege of serving on juries. For the most part, a voter ... need only show that he is 21 . . . a citizen, and not in jail, whereas a juryman may have to bc 25 years of age, the owner of property, of good character, intelligent, and fairly well-skilled. Moreover, in many states a commissioner of jurors or a county clerk has almost unlimited discretion to determine which persons meet the requirements. ..." Baker, In Defense of the 'Blue Ribbon' Jury, 35 Iowa L. Rev. 409, 415-16 (1950) (collecting statutes and representative cases).

${ }^{13}$ The jury, when functioning as law-dispenser, would thus be at odds with itself as capable finder of facts. Persons drawn at random from the entire community cannot be expected to meet the rigid intellectual requirements necessitated by the jury trial process. The more efficient the jury, ordinarily at least, the more unrepresentative. See Baker, op. cit. supra note 133, at 417. The New York Blue Ribbon juries, while far more "efficient" in the sense of convicting many more people, are scarcely drawn from the slums. See Comment, Blue Ribbon Juries, 47 Col. L. Rev. 463. (1947).

${ }_{135}$ The theory that the jury acts as law-dispenser is wholly inconsistent with the innumerable cases reversing trial courts for failing properly to instruct juries on legal principles. In another respect, however, the law-dispensing theory and reversals for improper instructions are consistent, as both assume that jurors understand the judge's instructions. 
flection of the close historical identification of the jury with freedom. More probably it is a result of the wide-spread feeling that the jury is more effective in criminal proceedings and that an accused is entitled to the best democracy can offer him. A third possible explanation is similar to the second but diametrically opposed to it. This is the theory that democracy's best is efficiency's worst and that criminal juries are worshipped for their aberrations because we are all potential criminals.

Probably no one of these three theories is entirely correct nor altogether wrong. Historically, of course, the traditional association of the criminal jury trial with freedom is erroneous. The jury originated as a purely administrative device designed to extend the power of a dictatorial monarchy. ${ }^{136}$ Only centuries later did it become the basis of a rebellion against absolutism. ${ }^{137}$ But the criminal jury's function as a protector of the individual against government is anomalous in far more than a simple historical sense. So long as the balance of power between government and the people rests with the former, twelve commoners of the vicinage can be expected to shield individuals fighting against government oppression. But when the balance of power is reversed, instead of opposing the government's attempted oppressions, jurors are more likely to favor them. From the time of the Alien and Sedition Acts, the government's attempted inroads on civil rights seem to have received the enthusiastic support of jurors. ${ }^{138}$ As Judge Amidon remarked after extensive experience with Espionage Act prosecutions during the First World War:

Only those who have administered the Espionage Act can understand the danger of such legislation.... Most of the jurymen have sons in the war. They are all under the power of the passions which war engenders. For the first six months after June 15, 1917, I tried war cases before jurymen who were candid, sober, intelligent business men, whom I had known for thirty years, and who under ordinary circumstances would have had the highest respect for my declarations of law, but during that period they looked back into my eyes with the savagery of wild animals, saying by their manner, "Away with this twiddling, let us get at him." Men believed during that period that the only verdict in a war case, which could show loyalty, was a verdict of guilty. ${ }^{130}$

${ }^{136}$ Forsyth, History of Trial by Jury 1-138 (1875).

${ }^{137}$ Ibid.

${ }^{138}$ As Chafee points out, "The transference of ... censorship from the judge to the jury is indeed important when the attack on the government which is prosecuted expresses a widespread popular sentiment, but the right to jury trial is of much less value in times of war or threatened disorder when the herd instinct runs strong, if the opinion of the defendant is highly objectionable to the majority of the population, or even to the particular class of men from whom or by whom the jury are drawn." Chafee, Free Speech in the United States 24 (1948); see also, Worts, "The Jury System" under Changing Social Conditions, 47 Am. L. Rev. 67 (1931).

${ }^{239}$ Chafee, op. cit. supra note 138 at 70 . 
Judge Amidon's experience has been mirrored in every period of panic and popular indignation from earliest times down to the present. ${ }^{140}$ But the case against the criminal jury as a protector of individual liberty extends further than to contests between government and citizens opposed to its policies. Minority groups have often suffered at the hands of jurymen. Wholesale acquittals of lynch-law violators, convictions of Negroes on the slightest evidence, and numerous other occurrences which have now almost become a part of the jury tradition might be instanced as examples.

The jury in criminal cases has another perhaps equally unpalatable aspect. In a democratic society, it is a definite obstacle to reform and innovation. As jurors will usually reflect the opinions of a majority of the community, so long as the majority itself remains unconvinced of the attempted reform's wisdom, juries will usually reflect a similar sentiment. Thus, artistic innovations have often been thwarted. In a few jurisdictions, obscenity convictions have been obtained for writing and publishing some of America's best literature. ${ }^{141}$ Writers and producers of the finest modern stage plays have often suffered similarly. ${ }^{142}$

Aside from the incidental psychological functions which the criminal jury is alleged to perform, the sole remaining virtue claimed for it lies in its ability to make allowances for the circumstances of the particular case - to dispense with a rule of law. As noted previously, however, law-dispensing is a two-edged sword, and there is no current means of ascertaining which way it more often swings. ${ }^{143}$ It may seriously be doubted whether entrusting the jury with law-dispensing powers is justified. While flexibility of legal administration is desirable, it would seem that the necessary

${ }^{140}$ It may be doubted, however, whether the judges have done any better. Nonetheless, Chafee concludes that, on the whole, "[t]he number of ... judges who ... [are] guilty of actually prejudicial conduct .... is comparatively few, and in many respects they [deserve] ... the praise which [was] ... awarded them for giving great latitude to the defendant's proof and urging upon the jury the necessity for the dispassionate consideration of evidence. The defect was, for the most part, not so much in what they said, as in what they did not say." Chafee, op. cit. supra note 138, at 77. The judges' sentencing of convicted political offenders, however, has not been equally commendable. Ibid., at 79.

141 Among others, the following books have failed to pass the jurors' stringent Victorian tests: An American Tragedy, Lady Chatterley's Lover, Reigen, and Strange Fruit. See Grant and Angoff, Massachusetts and Censorship, 10 B. U. L. Rev. 36, 147 (1930).

.112 Consult Chafee, op. cit. supra note 138, at 529-540; Comment, Literary Obscenity in New York, 47 Col. L. Rev. 686 (1947).

${ }^{143}$ Some of the more enthusiastic espousers of the jury, however, favor discrimination: "My uncle used to say. that the jury served the great purpose of ridding the neighborhood of its sons of bitches. Men have been convicted of murder in a jury's exercise of this function. ... [T] he jury sits in judgment on the offender as well as the offense.... My uncle was undoubtedly right in thinking that the jury often, and not always unjustifiably, confuses what a man is with what a man does." Curtis, op. cit. supra note 9, at 157. 
exceptions to the normal rules could with better reason be fashioned by the legislature or court. ${ }^{144}$

While literature dealing with the jury often reflects a belief that juries in criminal cases are "more reliable" than in civil cases, ${ }^{145}$ the rationale underlying this belief is not altogether clear. Its chief justification seems to rest in the comparatively less complex issues typically involved in criminal cases. An additional justification might be found in the more serious nature of criminal proceedings. Jurors in criminal cases deal in lives and freedom, not money damages, and should be expected to perform their tasks more efficiently. Whether they do so, however, may be doubted. Emotional pressures operative in civil proceedings are magnified many-fold in serious criminal cases. Instead of being confined solely to the courtroom such pressures are often exerted with tremendous force in the newspapers, on television and radio. ${ }^{146}$. The juror's native prejudices are more easily aroused in a criminal case and may, by the time he is selected for service, have been fanned to a fevered pitch by community outrage against the crime the defendant is accused of having committed. It is well known that frequent changes of venue are necessitated by the inability of veniremen to afford the defendant a fair trial, ${ }^{147}$ and cases have arisen in which the defendant's only alternatives were to run the risk of a biased jury or rot in jail because of inability to post bail or because bail had been denied. ${ }^{148}$ In most jurisdictions, the defendant is not allowed unilaterally

144 Referring to the Sedition Act prosecutions, Chafee notes the "well-known probability that juries will acquit, after the excitement is over, for words used during the excitement, which are as bad in their tendency as other writings prosecuted and severely punished during the critical period. ... It is also interesting to find two juries in different parts of the country differing as to the criminal character of similar publications or even the same publication. Thus Leigh Hunt was acquitted for writing an article, for the printing of which John Drakard was convicted. The acquittal of Scott Nearing and the conviction by the same jury of the American Socialist Society for publishing his book form an interesting parallel." Chafee, op. cit. supra note 138, at 25. And see United States v. American Socialist Society, 260 Fed. 885 (S.D.N.Y., 1919).

${ }^{145}$ Even the courts have occasionally expressed a similar preference. See, e.g., Sparf and Hansen v. United States, 156 U.S. 51, 173 (1895).

${ }^{146}$ See Note, Fair Trial and Biased Public Opinion, 3 Syracuse L. Rev. 150 (1951); Report of the Special Committee on Cooperation between Press and Radio and Bar, 62 A.B.A. Rep. 851,861 (1937).

The contempt power is wholly inadequate to combat these influences. See, e.g., Baltimore Radio Show Inc. v. Maryland, 193 Md. 300, 67 A. 2d 497 (1949); cert. denied, 338 U.S. 912 (1950); Note, Controlling Press and Radio Influence of Trials, 63 Harv. L. Rev. 840 (1950); Holtzoff, The Relation between the Right to a Fair Trial and the Right of Freedom of the Press, 1 Syracuse L. Rev. 369 (1950).

${ }^{147}$ See Jackson, J., concurring in Shephard v. Florida, 341 U.S. 50, 54 (1951).

14s See Moore v. Dempsey, 261 U.S. 86 (1923); Note, Fair Trial and Biased Public Opinion, op. cit. supra note 146 , at 151 . 
to waive judgment by his peers, ${ }^{149}$ and prosecutors eager for publicity are not always willing to give the required consent.

On the whole, the criminal jury's ability to measure up to the heavy tasks assigned it is seemingly no greater than that of juries handling noncriminal matters. The increased emotion attendant upon criminal trials probably warps the jury's fact-finding abilities in roughly the same degree as does the complexity of issues involved in civil cases. If juries are such excellent judges of character as one is often led to suppose, there appears to be no reason why sentencing powers ought not also to be entrusted to them ${ }^{150}$ and why courts should treat them with the tenderness one would accord children. ${ }^{151}$

\section{The Jury as a Means of Inducing Confmence in the Law}

In addition to its numerous other alleged functions, it is claimed that the jury system induces public confidence in the administration of justice. ${ }^{152}$ There are two aspects to this contention. First of all, the community is said to have more confidence in the judgment of laymen than of those who are learned in the law. But this first point may be disposed of briefly, for even if its correctness be conceded, it proves nothing about the degree to which public faith in the jury is justified. Secondly, public confidence in the administration of justice is said to arise out of the fact that complicated and occasionally insoluble factual disputes have the appearance of being settled with ease when wrapped in the silent garb of a verdict returned in supposed compliance with strict legal rules. The unanimity requirement itself seems to suggest that rational disagreement on the issues submitted to a jury is impossible. ${ }^{153}$ The jury enables the law to say: "No dispute is too tough; there is a definite legal solution for all problems." The precisional certainty engendered by the jury in turn induces respect for law and for legal institutions in general.

149 The states are about evenly divided on this question. In the federal system, Patton $v$. United States, 281 U.S. 276 (1930), has long been interpreted as denying to the accused the right to waive a trial by jury without the government's consent. Consult Knudson, Waiver of Trial by Jury in Felony Cases, 26 Ill. L. Rev. 85 (1931); Oppenheim, Waiver of Trial by Jury in Criminal Cases, 25 Mich. L. Rev. 695 (1927). Such rulings seem wholly inconsistent with the theory that the jury trial operates as a dispenser of mercy and as a protection against tyranny.

. ${ }^{150}$ See Comment, Consideration of Punishment by Juries, 17 Univ. Chi. L. Rev. 400 (1949).

${ }^{151}$ The operation of the numerous' evidential rules restricting the admission of testimony as frequently works against the accused as in his favor. As many of these rules are necessitated by the jury system itself, this is another instance in which trial by jury may prejudice innocent men, to say nothing of the guilty men who are thus enabled to go free.

${ }^{152}$ E.g., Wyzanski, A Trial Judge's Freedom and Responsibility, 65 Harv. L. Rev. 1281, 1284 (1952); Curtis, The Trial Judge and the Jury, op. cit. supra note 9, at 163.

${ }^{163}$ Emmit, The Nature of Metaphysical Thinking 142 (1949). 
The claim that the jury whose most familiar characteristic is its power to ignore the law somehow renders the law more certain in the process of dispensing with it seems at first almost incredible. There is, however, a small measure of truth in this claim. Reasoning powers are often incapable of coping with knotty factual disputes; and to the extent that jury magic can resolve them, legal certainty can in one sense be regarded as having been enhanced. To a large extent, however, the certainty which the jury provides is fictional. The air of mystery surrounding its deliberations, the uninforming nature of the verdict itself, the vast differences of opinion exhibited in the verdicts of different juries, together with the fact that verdicts are not reported and cannot be used as guides for the future all illustrate that the sort of certainty involved is only skin deep.

Nevertheless, the law has taken numerous steps to ensure that the fiction of certainty provided by juries does not become tarnished. A verdict cannot be impeached save under highly exceptional circumstances. ${ }^{154}$ Jurors have a testimonial privilege ${ }^{155}$ and perhaps even a legal duty ${ }^{156}$ not to disclose jury room deliberations. They cannot be polled concerning the means by which their decision was reached, either before or after the verdict has technically been received. ${ }^{157}$ It is only with the greatest difficulty that a verdict can ever be overthrown. The sanctity of the jury room has become a judicial fetish. The use of special interrogatories and special verdicts has been greatly restricted. ${ }^{158}$ Even today most judges exhibit surprising reluctance to require special verdicts; and Rule 38 of the Federal Rules of Civil Procedure has been interpreted to preserve the court's traditional discretion in this matter. ${ }^{159}$ The results which have obtained on those few

${ }^{154}$ Note, Affidavits of Jurors as Basis for a New Trial, 47 Col. L. Rev. 1373 (1947); Testimony of Jurors to Impeach Verdict, 10 Ohio St. L. J. 262 (1949).

${ }^{155}$ See 8 Wigmore, Evidence $\$ 2353$ (3d ed., 1940).

${ }^{156}$ The existence of any such duty is extremely doubtful in the United States. The only case which appears to have passed upon the question squarely holds that "there is no rule or provision of law or public policy that prohibits the informal interrogation of a juror after the return of a verdict. A juror so interviewed may respond or not as he sees fit. ..." Patrick v. Yellow Cab Co., 114 N.E. 2d 735, 736 (Ohio App., 1953). Of course any statements made by the juror concerning his or any other juror's conduct in the jury room is inadmissible for the purpose of impeaching the verdict in the absense of other evidence.

However, it is probable that a petit juror has an obligation of secrecy in England, at least in criminal cases. For there are dicta that, "[E]very juryman ought to observe the obligation of secrecy which is comprised in and imposed by the oath of the grand juror. If one juryman might communicate with the public upon the evidence and the verdict, so might his colleagues also; and, if they all took this dangerous course, differences of individual opinion might be made manifest, which, ... could not fail to diminish the confidence the public ... has in . . criminal verdicts." Rex v. Armstrong, 16 Cr. App. R. 149, 159 (1922).

${ }^{157}$ See notes 2 and 3 supra. 158 Ibid.

${ }^{159}$ Skidmore v. Baltimore \& Ohio R. Co., 167 F. 2d 54 (C.A. 2d, 1948); Marcus Loew Booking Agency v. Princess Pat, 141 F. 2d 152 (C.A. 2d, 1944). 
occasions when jury room secrecy has been bared are astounding-quotient verdicts, prejudice, fraud, and ignorance of what has previously transpired in the court room..$^{160}$

\section{The JuRy as an Educating Force in the Community}

Jury service furnishes the only means, other than by voting, through which the citizen can actually participate in the administration of government. Service on a jury gives one a sense of community responsibility. It acquaints the citizen with justice as it is practically administered. ${ }^{161}$ of this, there can be no doubt.

But what of the litigants? The fact that jury service educates thrusts more than one way. Certainly those who must submit themselves to a trier of fact are entitled to someone more capable than people going to jury school for the first time. If citizens really have to serve on juries in order to become aware of how justice is practically administered, they must, in practice, prove highly incompetent jurors. To the extent that the jury does operate as an educating force, however, its worth must be measured against its inefficiency in other respects. The creation of responsibility in jurors is only incidental to the jury's more central functions. The jury was not instituted as a substitute for education, but as a means of trying lawsuits.

But the educational force of jury service can be questioned on more than a theoretical level. In most jurisdictions the period of service is extremely short, ordinarily but two weeks. And little effort has been made to train jurors in what they are supposed to do. Simple indoctrinating handbooks have been judicially proscribed in Illinois, ${ }^{162}$ and their use is optional in the federal system and in the few states which provide them. ${ }^{163}$ Jury schools are unheard of; we first prefer to test citizens on litigants.

${ }^{160}$ Hunter found that, "In many if not in most of the cases which were followed in this study the amount of the verdict was determined by balloting and obtaining a quotient." Hunter, Law in the Jury Room, 2 Ohio St. L. J. 1, 17 (1935). For actual cases, see the references in the opinion of Frank, J., in Skidmore v. Baltimore \& Ohio R. Co., 167 F. 2d 54 (C.A. 2d, 1948).

181 "Jurors are observers, to see how the judicial process works and how the judges behave. It is our way of insisting that citizens visit the courts from time to time and report to each other on the administration of justice." (!) Curtis, The Trial Judge and the Jury, op. cit. supra note 9 , at 157 .

102 People v. Schoos, 399 Tll. 527, 78 N.E. 2 d 245 (1948), noted 62 Harv. L. Rev. 140 (1948). The handbook is reprinted in Miner, The Jury Problem, 41 Ill. L. Rev. 183, 187 (1946). The court left open the question of whether the use of the handbooks violated the constitutional right of trial by jury.

${ }^{183}$ See Knabe, Juror's Handbook, 5 Ala. Lawyer 195 (1944); Report to the Judicial Conference of the Committee on Selection of Jurors 10 (1942). 
The probability that many jurors fail to grasp the significance of the court's instructions and even, in many cases, to comprehend the complex factual issues submitted to them for decision, instead of encouraging a sense of community responsibility; might be expected to derogate from it. Removing jurors from their private jobs and forcing them to assume heavy economic sacrifices in order to sit in judgment hefore issues which some of them cannot even understand can only encourage disrespect for the law. Finally, many jurors do not want the kind of education that jury service is claimed to provide. The costs are too great in relation to what is learned. Resultant attempts to secure exemption from service are widespread. Jury service is familiarly regarded as irksome. ${ }^{164}$

\section{The Jury as an Escape from Judicial Bias and Corruption}

Unfortunately, there can be little doubt that many judges have exhibited bias and that some judges are corrupt. ${ }^{165}$ Perhaps to some extent juries have functioned as a counteracting force. But the ultimate answer to judicial bias and corruption is not more juries, but better judges. Furthermore, those instances in which judges are likely to be biased and corrupt are often cases in which the jury would be powerless to act if it would. The corrupt or biased judge directs verdicts or rules at odds with the law on questions such as the admissibility of testimony; or the jury's verdict may be set aside as against the weight of the evidence; or the judge may declare himself in error on a previous legal ruling and direct a new trial. Even in those instances where the jury could act to thwart illicit judicial sympathies, the judge's prejudice, rather than being counterbalanced by the jury, may be complemented by it. Either the jury may be biased in the first place, or the judge, with a know-how born of experience, may render it so. Finally, the prejudice problem, while troublesome in the case of judges, is far more pronounced in the case of juries. Typically, the judge restrains the jury, not the other way around.

In one rather large body of cases, however, the jury may operate as a significant mainstay against judicial bias and corruption. In criminal

${ }^{164}$ While there is little direct evidence on this point, this is certainly the inference to be drawn from the frequent attempts of organized groups to secure legislative exemption for their members.

${ }^{165}$ Consult Haines, General Observations on the Effects of Personal, Political and Economic Influences in the Decisions of Judges, 17 III. L. Rev. 96 (1922); Schroeder, The Psychologic Study of Judicial Opinions, 6 Cal. L. Rev. 89 (1918). Alexander Hamilton regarded this consideration as the strongest argument in favor of adopting a federal constitutional amendment preserving the trial by jury in civil cases. Yet he felt that "[t]he force of ... [the] consideration ... [was] diminished by others" which appeared to outweigh it. Hamilton, of course, opposed such an amendment. Federalist Papers, No. 83, pp. 140-41 (Tudor Pub. Co. ed., 1947). 
cases, judges often acquire a vested interest in law enforcement; continuance in office often turns on the number of convictions which can be paraded before an electorate. The judge's friend and fellow political worker is often the prosecuting attorney or one of his subordinates or, on the other hand, the defendant's attorney. Similar considerations may produce undue judicial sympathy for one of the litigants in civil proceedings. In all of these cases, the jury is often a definite social asset. Significantly, however, most of the instances mentioned stem from the circumstance that judges are elected, often for short terms and subject to recall..$^{166}$ Federal judges are not nearly so suspectible to influences which juries are in a position to correct, even if it is assumed that they would wish to.

Probably society does not take with any great degree of seriousness the claim that juries can successfully counteract judicial bias. In criminal cases, the judge's bias is most frequently reflected in the severity of his sentences, not in the manner he conducts the trial. ${ }^{167}$ A jury wishing to counteract this severity can only acquit. If an attempt is made to secure a definite indication of the degree of punishment to be imposed, reversible error will almost automatically result. ${ }^{168}$ Yet we are afraid to bestow sentencing powers upon juries, both for fear of their abuse and of the jury's inability to consider questions of punishment apart from those involving guilt. ${ }^{169}$ It is only in a very narrow area in which the jury can ever successfully function as a device for thwarting judicial bias or corruption.

\section{VIIT. OTHER Functions OF THE JURY}

In addition to the more or less important tasks the jury is claimed to discharge, numerous incidental functions are also allegedly performed by it. Most of these alleged incidental functions, however, are but fictions devised by advocates of the jury system in order to bolster their main arguments.

Perhaps the most significant of these claims is the claim that the jury provides a means by which judges can avoid deciding complex questions and thus avoid the criticism which always follows from being forced to decide between two equally plausible alternatives. Judges should be men of

106 Consult Haynes, The Selection and Tenure of Judges (1944).

${ }^{167}$ See Gaudet, Individual Differences in the Sentencing Tendencies of Judges (1938). This study was conducted under the supervision of Professor Karl Llewellyn.

${ }^{268}$ For an exhaustive consideration of the problems involved, see Comment, Consideration of Punishment by Juries, 17 Univ. Chi. L. Rev. 400 (1949).

${ }^{169}$ Other possible reasons are: (1) we wish to give the sentencing power to judges because of their superior experience, or to parole boards for similar reasons; or (2) we wish to keep the sentencing power in the hands of one upon whom public opinion can focus. 
dignity; to force them to guess and rationalize about facts encourages disrespect both $\cdot$ for themselves and the entire legal system. ${ }^{170}$ Significantly, perhaps, most of the outspoken defenders of the jury are trial judges. ${ }^{171}$

This argument is really but a variation of the theme that the jury supplies legal certainty and that a fiction about the ease with which facts can be decided is desirable in itself. ${ }^{172}$ Many of the criticisms offered in refutation of the claim that the jury provides legal certainty are equally applicable to the contention that the jury assists judges to maintain proper respect for themselves. ${ }^{173}$

In addition, as Judge Frank has pointed out, "Men fit to be trial judges should be able and willing to accept public criticism. Moreover, they are obliged to do so in the many cases they must try without juries. Probably ... [the argument that the jury acts as an insulator against public criticism of the judge] is but an ingenious rationalization."'174

It has also been urged that the jury offers an excellent form of popular entertainment which incidentally encourages citizens to take a more active interest in programs calculated to prevent crime. There is, however, no necessary connection between entertainment interest in jury trials and programs calculated to prevent crime; indeed, it might be expected that the result of watching at least some trials would produce an opposite effect. Trial before a judge sitting without a jury, while not as entertaining, possesses far more of the qualities which induce interest in crime prevention. Furthermore, the jury trial is a highly expensive form of entertainment, ${ }^{175}$ and there is no reason why particular litigants should be expected to foot the community's entertainment bill.

The drama popularly associated with the jury is also occasionally urged as being responsible for attracting into the legal profession its most able and distinguished members. It is more than likely, however, that jury trials have discouraged more able men from entering the law than they have encouraged. Exhibitionistic lawyers gesticulating before juries are often the greatest actors in the world, but may not be the best men safely and conscientiously to handle other persons' affairs. The emotionalism attendant upon jury trials has an even more undesirable effect upon the

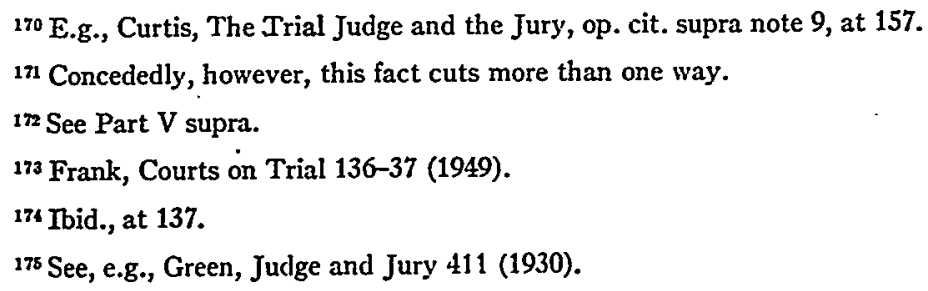


legal profession. ${ }^{176}$ As Professor Thayer has observed, the jury trial "appears to . . . be a potent cause of demoralization to the bar."177 Crying, pleading and weeping before juries is not attractive to most lawyers and contributes heavily to the impression, often expressed, that "they are all shysters."

Finally, it has even been claimed that the jury trial operates as a preventer of litigation and the facilitator of compromise. ${ }^{178}$ Briefly, the contention is that the outcome of a jury trial is so uncertain and hinges upon such a multitude of imponderables that litigants, rather than risking a complete loss, will compose their differences out of court. But the coerced compromise of valid claims is not desirable, and to the extent that the aberrations of jurors are responsible, such compromises are unjustified. Many of the compromises for which the jury system is to blame, however, are not chargeable to any particular jury. The vast web of evidential rules, the trial judge's instructions upon the law, errors in the composition and selection of the jury, and a host of other sources of error necessitated by the jury system offer added inducement to compromise. Congested court dockets and resultant delays in the ultimate decision of controversies furnish a still additional reason for settlement. Much of this congestion is due to the jury trial. The familiar claim that juries are plaintiff-prone may well be counterbalanced by the money insurance companies save by forcing

${ }^{176}$ And also, of course, on the trial itself. There is little doubt that lawyers are motivated to "show-off" or be dramatic in jury trials. Green, Judge and Jury 397 (1930). Green's observations were just recently corroborated by the results of the Missouri Law School experiments. See Hoffman and Brodley, Jurors on Trial, 17 Mo. L. Rev. 235, 246 (1952).

The inherently competitive courtroum atmosphere, accentuated by the presence of jurors, is largely responsible for the belief that the jury often tries the lawyers rather than the issues. This belief is also fortified by the Missouri experiments. "[Seventy-five per cent] of those who thought there was any difference in the ability of counsel voted for the side represented by the attorney they would hire." Ibid., at 243.

177 Quoted by Frank, Courts on Trial 124 (1949). The inability of lawyers to predict the outcome of litigation also affords a convenient self-rationalizing device for the adoption of illegal practices calculated to secure victory.

${ }^{178} \mathrm{~A}$ related argument, suggested by Curtis, is that jury verdicts reduce the number of appeals and hence save litigation expense. As contrasted with the findings of the trial judge, appellate court doctrines afford greater weight to a general verdict. Curtis argues that the rationale underlying this difference is found in the similarity of training between trial and appellate court judges. The layman's judgment, being the result of disciplines (or, it may be, lack of disciplines) with which appellate judges are unfamiliar, must be accorded greater respect. Even assuming that Curtis' suggested rationale is correct, the thrust of his observation goes both ways: erroneous jury verdicts will be sustained where they should be reversed.

Probably, however, the rationale underlying the added respect appellate courts pay to jury as contrasted with trial-judge verdicts lies in the requirement that trial judges must make specific findings of fact. Knowing what has occurred, appellate courts are then in a position to act. See Findings of Fact and Conclusions of Law in Cases Where Juries Are Waived, 4 Univ. Chi. L. Rev. 218 (1937); Curtis, The Trial Judge and the Jury, op. cit. supra note 9 , at 158 n. 16. 
harsh settlements upon injured persons in need of money to pay doctor bills. ${ }^{179}$

Sophisticated canonizing of juror inefficiency has a slightly different basis in criminal as contrasted with civil cases. The widespread feeling that juries in criminal cases are defendant-prone, frequently acquitting for reasons the law cannot recognize and sociologists cannot even understand, coupled with the notion that everyone is a potential defendant induces respect for inefficiency. ${ }^{180}$ As pointed out above, ${ }^{181}$ however, defendants need protection against unjust convictions quite as much as society requires the conviction and punishment of those who have committed crimes. It is doubtful, however, whether popular theories concerning the leniency of criminal juries are justified. In any event, the notion that the jury is good because of its refusal to do what it is legally supposed to, and because we respect inefficiency, is wholly irrational.

\section{Conclusion}

It is doubtful whether the jury has fulfilled the expectations which the innumerable functions claimed for it seem to portend. This would seem true not only of the strictly legal tasks which have been assigned to it, but of its so-called "incidental" and "extra-legal" functions as well. Concededly, however, there is an element of fraud involved in any attempt to appraise the jury system's efficiency. In the absence of empirical data, value judgments all too readily creep in to substitute for facts. Value judgments, however, do not constitute the basis for the inconsistencies found in the functions ascribed to the jury and in the numerous rules governing. their performance. Illicitly expecting the jury to do one thing while legally charging it with doing the opposite, and formulating rules so that neither expectation nor legal duty can successfully be realized, are alone sufficient to establish a prima facie case against the jury. Suggestions concerning the extent to which the law of the jury should be changed, however, are beyond this article's province. Empirical investigation may demonstrate that the conclusions arrived at here are to some extent unsupported in fact, and that certain of the inconsistencies between the functions imputed to the jury and the rules guiding their execution are possibly superficial. ${ }^{182}$

179 It is doubtful, however, whether the claim that juries are plaintiff-prone is justified. See Green, Judge and Jury 405 et seq. (1930). Compare James, Functions of Judge and Jury in Negligence Cases, op. cit. supra note 98 , at 687 .

180 Seagle, Law: The Science of Inefficiency 120 et seq. (1952),

181 Part IV supra.

182 See note 5 supra and accompanying text. 